\title{
Dinocyst and acritarch biostratigraphy of the Late Pliocene to Early Pleistocene at Integrated Ocean Drilling Program Site U1307 in the Labrador Sea
}

\author{
Aurélie Marcelle Renée Aubry ${ }^{1}$, Stijn De Schepper ${ }^{2}$, and Anne de Vernal ${ }^{1}$ \\ ${ }^{1}$ Geotop, Université du Québec à Montréal, CP 8888, \\ Succursale Centre-Ville, Montréal, QC, H3C 3P8, Canada \\ ${ }^{2}$ NORCE Climate, NORCE Norwegian Research Centre, \\ Bjerknes Centre for Climate Research, Jahnebakken 5, 5007 Bergen, Norway \\ Correspondence: Aurélie Marcelle Renée Aubry (aurelieaubry@gmail.com)
}

Received: 17 July 2019 - Revised: 7 January 2020 - Accepted: 13 January 2020 - Published: 19 March 2020

\begin{abstract}
We have analyzed marine palynomorphs (mainly dinocysts and acritarchs) from the Integrated Ocean Drilling Program Site U1307 in the Labrador Sea in order to establish a detailed biostratigraphy for the Late Pliocene to Early Pleistocene. We have defined three magnetostratigraphically calibrated dinocyst and acritarch biozones in the Late Pliocene to Early Pleistocene. Zone LS1 is defined based on the highest occurrence of Barssidinium graminosum and covers the later Pliocene from 3.21 to $2.75 \mathrm{Ma}$. Zone LS2 is marked by the acme of Pyxidinopsis braboi which occurs between 2.75 and $2.57 \mathrm{Ma}$, thus encompassing the Plio-Pleistocene transition. Finally, zone LS3 extends from 2.57 to $2.23 \mathrm{Ma}$ in the Early Pleistocene.

The palynostratigraphic record of IODP Site U1307 is difficult to correlate to other North Atlantic and Nordic Seas sites mainly because of a different temporal resolution and a lack of well-defined biostratigraphic marker species at the basin scale. The low abundance, discontinuous occurrence and asynchronous events of warm-water Pliocene taxa such as Invertocysta lacrymosa, Impagidinium solidum, Ataxiodinium confusum, Melitasphaeridium choanophorum and Operculodinium? eirikianum suggest cooler conditions in the Labrador Sea than elsewhere in the North Atlantic, reflecting a strong regionalism. Nevertheless, as recorded at other locations in the North Atlantic, the disappearance of many dinocyst and acritarch taxa around 2.75 Ma at Site U1307 reflects a strong ecological response accompanying the intensification of the Northern Hemisphere glaciation.
\end{abstract}

\section{Introduction}

The Cenozoic was marked by large tectonic, paleoceanographic and paleoclimatic events that ultimately led to the initiation and the intensification of the Northern Hemisphere glaciations (iNHG; Shackleton et al., 1984; Mudelsee and Raymo, 2005). Well-constrained chronologies are crucial for documenting and better understanding the paleoceanographic conditions and paleoclimatic changes around the iNHG at the end of the Cenozoic. However, the stratigraphic control is limited due to poor carbonate preservation in high-latitude oceans, and this hampers accurately documenting and understanding the paleoceanographic and climatic change around this time. The temporal coverage of existing stratigraphic schemes is often incomplete or the resolution is too low (Harrison et al., 1999). Mattingsdal et al. (2014) demonstrated the importance of a robust chronology to reconstruct the regional history of the Fram Strait gateway in order to better understand exchange between the Arctic and Atlantic oceans as well as the intensification of glaciation in the Barents Sea and on Svalbard. Today, uncertainties remain about the relationships between the different ocean gateways, including the Bering Strait, the Canadian Arctic Archipelago, the Fram Strait and Isthmus of Panama and their implication in the intensification of the Northern Hemisphere glaciation (iNHG; Sarnthein et al., 2009; Matthiessen et al., 2009).

The Labrador Sea is well located to document past climate and ocean circulation in relation with the Northern Hemi- 
sphere glaciation because of its proximity to Greenland and northeast North America, which permits the identification of important phases of glacial activity of the Greenland and Laurentide ice sheets through its sedimentary input (Thiede et al., 2011; Andrews and Tedesco, 1992). The Labrador Sea is also a transitional basin between Baffin Bay and the western North Atlantic (Fig. 1), where winter convection presently accounts for a part in the Atlantic Meridional Overturning Circulation (AMOC; Weaver et al., 1999; Yashayahev, 2007; Yashayahev et al., 2007). Two main surface currents characterize the Labrador Sea. Along the Greenland margins, the West Greenland Current (WGC) is composed of the warm waters from the North Atlantic Drift (NAD) mixing with cold waters of the East Greenland Current. Along the Canadian margins, the Labrador Current (LC) flows southward, carrying cold waters from the Arctic via Baffin Bay and the Hudson Strait. Hence, the paleoceanography of the Labrador Sea should permit to document the exchange between the Arctic and the North Atlantic. However, in the Labrador Sea as in many high-latitude settings, biostratigraphy and paleoceanographic reconstructions from deep-sea sediments are challenging because of the low preservation of biosiliceous and calcareous microfossils (e.g., Baldauf et al., 1989). Hence, in the Neogene sediments of the subpolar North Atlantic and North Pacific oceans, organic-walled microfossils such as dinoflagellate cysts (hereafter dinocysts) and acritarchs are very useful to establish biostratigraphical schemes (Louwye et al., 2004; De Schepper and Head, 2008a, b, 2009; De Schepper et al., 2009, 2014, 2017; Dybkjær and Piasecki, 2010; Verhoeven et al., 2011; Schreck et al., 2012; Zorzi et al., 2019). Since the 1980s, several regional studies across the North Atlantic and the Nordic Seas (the Iceland Sea and the Norwegian Sea) have led to the improvement of the taxonomy of dinocysts and acritarchs (Head, 1993, 1996, 1997; Versteegh and Zevenboom, 1995; Head and Norris, 2003; De Schepper et al., 2004; De Schepper and Head, 2008a, 2014; Schreck et al., 2012; Verhoeven et al., 2014) and to the development of calibrated biozonations that may allow correlations (De Schepper and Head, 2009; Schreck et al., 2012; De Schepper et al., 2017). Moreover, the paleoecological affinities of extinct Neogene taxa were also explored to better understand the significance of bioevents (De Schepper et al., 2009, 2011; Hennissen et al., 2015, 2017; Schreck et al., 2017).

The number of studies dealing with Neogene dinocysts and acritarchs in the western part of the subpolar North Atlantic remains limited and their spatial coverage is incomplete. Only a few sites drilled in the northwestern North Atlantic cover the Pliocene. They include the Ocean Drilling Program (ODP) sites 646 off southwest Greenland, 647 in the south central Labrador Sea, 645 in Baffin Bay and the Integrated Ocean Drilling Program (IODP) sites U1306 and U1307, both located at the southern tip of Greenland on the Eirik Drift in the Labrador Sea (Fig. 1) (Baldauf et al., 1989; Channell et al., 2010; Blake-Mizen et al., 2019). In the Labrador Sea, marine palynological studies at the above mentioned ODP sites have led to coarse-resolution biostratigraphy of dinocysts and acritarchs encompassing the upper Miocene to Pleistocene (de Vernal and Mudie, 1989; Head et al., 1989). At ODP Site 646, de Vernal and Mudie (1989) defined five biostratigraphic zones encompassing the Early Pliocene ( $\sim 5.4 \mathrm{Ma})$ to Holocene $(0 \mathrm{Ma})$ based on acmes and the common occurrence of dinocyst and acritarch taxa. The age model was based on calcareous nannofossil biostratigraphy (Knüttel et al., 1989) and magnetostratigraphy (Clement et al., 1989). The dinocyst biostratigraphy of de Vernal and Mudie (1989) deserves to be revisited in the light of the new dinocyst descriptions (cf. above) and because of the low resolution of the initial stratigraphic study. Here, we focus on the nearby and more recently drilled IODP Site U1307 $\left(58^{\circ} 30.3^{\prime} \mathrm{N}, 46^{\circ} 24^{\prime} \mathrm{W}\right.$; Fig. 1), where a continuously spliced sedimentary sequence has been recovered, and a detailed age model was established (Blake-Mizen et al., 2019). The present study has been undertaken to establish a detailed palynostratigraphy covering the Late Pliocene to Early Pleistocene in the Labrador Sea with the double objective of (i) identifying bioevents that may be used for a biostratigraphic purpose on a large scale and (ii) to pinpoint dinocyst and acritarch assemblage transitions that represent regional ecological response to ocean change. To do so, we have defined biozones and bioevents which we compare to calibrated dinocyst and acritarch biostratigraphic schemes from the North Atlantic and Nordic Seas (Head and Norris, 2003; De Schepper and Head, 2008a, b, 2009, 2014; De Schepper et al., 2017).

\section{Materials and methods}

\subsection{Marine sediments}

IODP Site U1307 is located near the southern tip of Greenland $\left(58^{\circ} 30.3^{\prime} \mathrm{N}, 46^{\circ} 24^{\prime} \mathrm{W}\right)$ at a water depth of $2575 \mathrm{~m}$ on the Eirik Drift (Fig. 1). Two holes (U1307A and U1307B) were drilled, reaching a maximum depth of $162.6 \mathrm{~m}$ below sea floor (mb.s.f.). The composite sequence from the two holes yields a complete and an almost continuous section of $\sim 175 \mathrm{~m}$ of Late Pliocene through Holocene sediments.

The lithology has been divided into three units from the top to the bottom (Expedition 303 Scientists, 2006). Unit I (49.55-0 m c.d. - meters composite depth) consists of predominant silty clays containing foraminifers and foraminifer and nannofossil oozes. Unit II (49.55 to $133.86 \mathrm{~m} \mathrm{c.d}$.) consists almost exclusively of silty clay. Unit III (133.86 to $173.6 \mathrm{~m}$ c.d.) consists mainly of silty clay, silty clay with nannofossil oozes and occasional diatom mats. All samples for this study were collected from the lower part of Unit II and Unit III between 116.43 and 172.99 m c.d. 


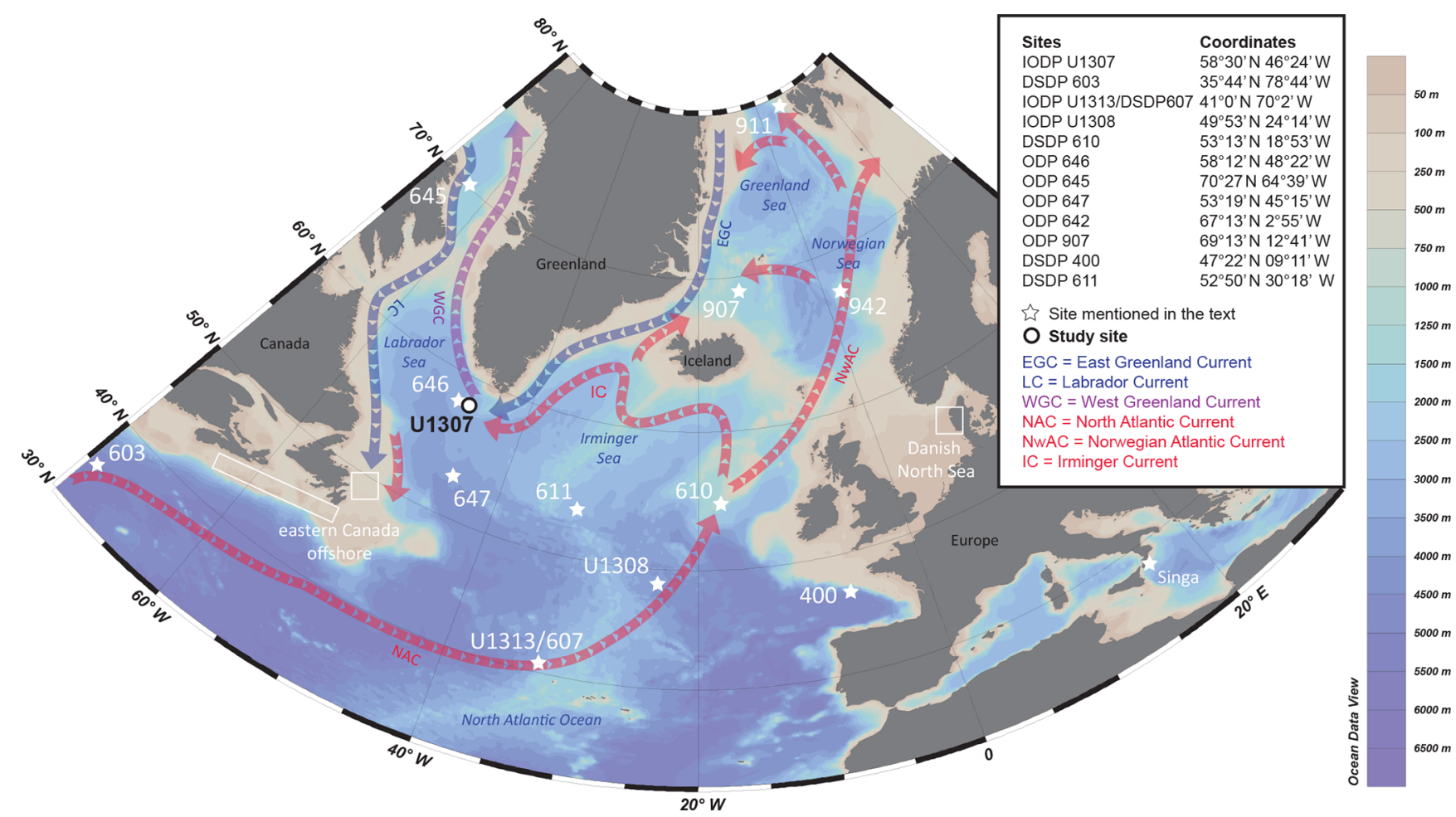

Figure 1. Map of the Labrador Sea showing the location of Site IODP U1307, other sites mentioned in the text and the modern surface currents (made with Ocean Data View; Schlitzer, 2018).

\subsection{Palynological work}

\subsubsection{Palynological preparation}

The 178 samples were prepared in two different laboratories. A total of 126 samples were treated with the standard palynological preparation method of de Vernal et al. (1999) and processed at the micropaleontological laboratory of Geotop at UQAM. Samples were first dried and weighed prior to being wet sieved on 10 and $106 \mu \mathrm{m}$ mesh sieves. One Lycopodium clavatum spore tablet (Batch no. 177745 with $n=18584 \pm 829$ spores; no. 124961 with $n=12542 \pm$ 931 spores; no. 483216 with $n=18583 \pm 1708$ spores; and no. 3862 with $n=9666 \pm 671$ spores per tablet) was added to the remaining 10-106 $\mu \mathrm{m}$ fraction and digested in warm hydrochloric acid $(\mathrm{HCl} ; 10 \%)$ to remove carbonate particles. This was followed by a hydrofluoric acid (HF; 49\%) treatment to dissolve silicates. Between each step samples were washed with water. Finally, the residues were sieved again on a $10 \mu \mathrm{m}$ mesh sieve. In addition, heavy liquid separation in a solution of sodium polytungstate calibrated for a specific density of 2 was used (Munsterman and Kerstholt, 1996) for the removal of the remaining silicates and heavy minerals. According to Mertens et al. (2009), heavy liquid separation does not bias the results. Residues were mounted on microscope slides with glycerin jelly.

The 52 remaining samples were prepared at Palynological Laboratory Services Ltd (Holyhead, UK) and followed the palynological preparation described in De Schepper et al. (2017). The samples were dried, weighed and put in a beaker. One Lycopodium clavatum spore tablet (Batch no. 483216 with $n=18583 \pm 1708$ spores and no. 124961 with $n=12542 \pm 931$ spores per tablet) was added prior to chemical degradation with cold acids. First, $\mathrm{HCl}(50 \%)$ was added, followed by adding water and sieving using a $10 \mu \mathrm{m}$ sieve cloth. The collected residue was returned to the beaker and $100 \mathrm{~mL} \mathrm{HF} \mathrm{(60 \% )} \mathrm{was} \mathrm{added.} \mathrm{After} \mathrm{dilution} \mathrm{with} \mathrm{water,}$ the residue was again sieved using a $10 \mu \mathrm{m}$ sieve cloth. Oxidation or ultrasound was not used. Polyvinyl alcohol (1\%) was added to the residue to prevent clumping, and some samples were stained with Safranin O. Residues were mounted on microscope slides with glycerin jelly.

\subsubsection{Microscopic analysis and counts}

The microscope analyses of 143 samples were done by Aurélie M. R. Aubry using a Leica DMR microscope, while 35 samples were counted by Stijn De Schepper using a Zeiss Axio Imager A2 microscope. All counts were done using transmitted light at $400 \times$ and $1000 \times$ magnification. Dinocyst and acritarch assemblages were the focus of this study, but spores, pollen grains, benthic foraminifer linings, freshwater algae and reworked palynomorphs were also enumerated. Reworked palynomorphs were distinguished based on the preservation state and/or their known extinct range. 
The concentrations of palynomorphs were calculated using the marker grain method of Stockmarr (1971) and are reported as specimens per gram (g) of dry sediment with an approximate error of $\pm 10 \%$ for a confidence interval of 0.95 (de Vernal et al., 1987; Mertens et al., 2009). The stratigraphic occurrence of selected dinocyst and acritarch taxa is reported in Fig. 3 with reference to absolute abundance as follows: occasional $\left(<10\right.$ cysts $\left.\mathrm{g}^{-1}\right)$, few $(10$ 100 cysts $\left.^{-1}\right)$, common (100-1000 cysts $\left.\mathrm{g}^{-1}\right)$ and abundant $\left(>1000\right.$ cysts $\mathrm{g}^{-1}$ ).

The list of taxonomic names and their full authorial citations of taxa encountered in this study is presented in Data S1 in the Supplement. Raw data are available in Data S2.

\subsubsection{Taxonomy and nomenclatures}

The taxonomic nomenclature follows the DINOFLAJ3 database of Williams et al. (2017). Some taxa were only grouped into generic categories when identification at the species level was equivocal, such as the following: Spiniferites/Achomosphaera spp., Impagidinium spp., Lejeunecystsa spp. and Operculodinium spp.

The identification of the "round hairy" cysts was not always easy, and sometimes it was not possible to distinguish the crucial morphological features of Filisphaera filifera, Filisphaera microornata and Bitectatodinium tepikiense. This led us to group some specimens as Filisphaera spp. or Filisphaera/Bitectatodinium indet. when classification to the species level was not possible. The subspecies Filisphaera filifera filifera and Filisphaera filifera pilosa (Head, 1993) were grouped as Filisphaera filifera. The vermiculate and columellate forms of Bitectatodinium tepikiense were identified but grouped as Bitectatodinium tepikiense.

\subsection{Age model, resolution and uncertainties}

The age model established in the initial report of the expedition was mainly based on nannofossil and magnetostatigraphic datums (Fig. 2; Expedition 303 Scientists, 2006; Channell et al., 2010). Stable isotope measurements on planktonic foraminifera (Neogloboquadrina atlantica) from 117.64 to $173.32 \mathrm{~m}$ c.d. and a correlation with the LR04 benthic foraminiferal $\delta^{18} \mathrm{O}$ stack of Lisiecki and Raymo (2005) led Sarnthein et al. (2009) to propose another age model. Hence, there were two different age models for the interval spanning from 2.6 to $3.6 \mathrm{Ma}$, both relying on the shipboard magnetostratigraphy and biostratigraphy (Expedition 303 Scientists, 2006; Channell et al., 2010). The age models differed in the identification of the Kaena and Mammoth magnetic events and in the position of the pronouncedly cold marine isotopic stage (MIS) M2 in the $\delta^{18} \mathrm{O}$ record (Fig. 2). Sarnthein et al. (2009) also used the highest occurrence (HO) of two dinocyst species, Operculodinium? eirikianum and Barssidinium pliocenicum, as tie points for the isotopic stratigraphy at $\sim 3.3 \mathrm{Ma}$. However, the HOs of these species have been shown to be asynchronous in the North Atlantic and the Nordic Seas (De Schepper et al., 2015, 2017), and the age of 3.3 Ma based on correlation with the discontinuous ODP Hole 646B sequence (de Vernal and Mudie, 1989; Clement et al., 1989) was not warranted. Further uncertainty about using these dinocyst events comes from the resolution of the shipboard palynological analyses for Site U1307. As the onboard analyses were done in core catcher sediments, the intervals between samples was at least $10 \mathrm{~m}$ (Expedition 303 Scientists, 2006; Channell et al., 2010).

Recently, Blake-Mizen et al. (2019) published a new highresolution magnetic susceptibility record and proposed a revised chronostratigraphy for IODP Site U1307. Their age model spans the last $\sim 3.2 \mathrm{Myr}$ and is based on magnetostratigraphic reversals and the relative paleointensity (RPI), which was tuned to the RPI of IODP Site U1308 (Channell et al., 2016). The lowest paleomagnetic reversal is identified to be at the top of the Mammoth subchron (3.20 Ma) and not the Gauss-Gilbert reversal (3.58 Ma) as previously thought (Expedition 303 Scientists, 2006; Sarnthein et al., 2009; Channell et al., 2010).

For this study, we used the new IODP U1307 splice and age model (Table 1) established by Blake-Mizen et al. (2019), which is continuous for an interval encompassing the Late Pliocene to Holocene. For each of our samples, we converted meters below sea floor (m b.s.f.) in holes U1307A and U1307B to revised meters composite depth (rmcd) according to the splice of Blake-Mizen et al. (2019). We calculated the age for each sample based on linear interpolations between their age model tie points (Table 1).

The error of paleomagnetic reversal age corresponds to half the age difference between the two samples that record the reversal (Weaver and Clement, 1987). In IODP Site U1307 cores, the extent of the reversals varied from 32 to $77 \mathrm{~cm}$ with an average of $48 \mathrm{~cm}$. Considering an average sedimentation rate of $\sim 6 \mathrm{~cm} \mathrm{kyr}^{-1}$ (Blake-Mizen et al., 2019) the error ranges from 5.3 to $12.8 \mathrm{kyr}$. The sampling resolution also affects the accuracy of the highest occurrence (HO) and lowest occurrence (LO) because the real disappearances and appearances may occur anywhere between the analyzed samples (see Versteegh, 1997). We analyzed a total of 178 sediment samples between 116.43 and $175.11 \mathrm{rmcd}$, with the sample spacing varying between 1 to $400 \mathrm{~cm}$ (average $33 \mathrm{~cm}$ ). This corresponds to a time resolution of 0.1 to $30 \mathrm{kyr}$ (average $5.5 \mathrm{kyr}$ ), which thus applies to the error in the timing of $\mathrm{HO}$ and $\mathrm{LO}$.

\subsection{Origin of particles (dinocysts and acritarchs)}

Lateral particle transport can be relatively high in the Labrador Sea due to the surface currents (EGC) and deep circulation (Western Boundary Under Current - WBUC; Nooteboom et al., 2019). Based on high-resolution sedimentological records, Blake-Mizen et al. (2019) inferred that bottom current dominated depositional processes at IODP Site 


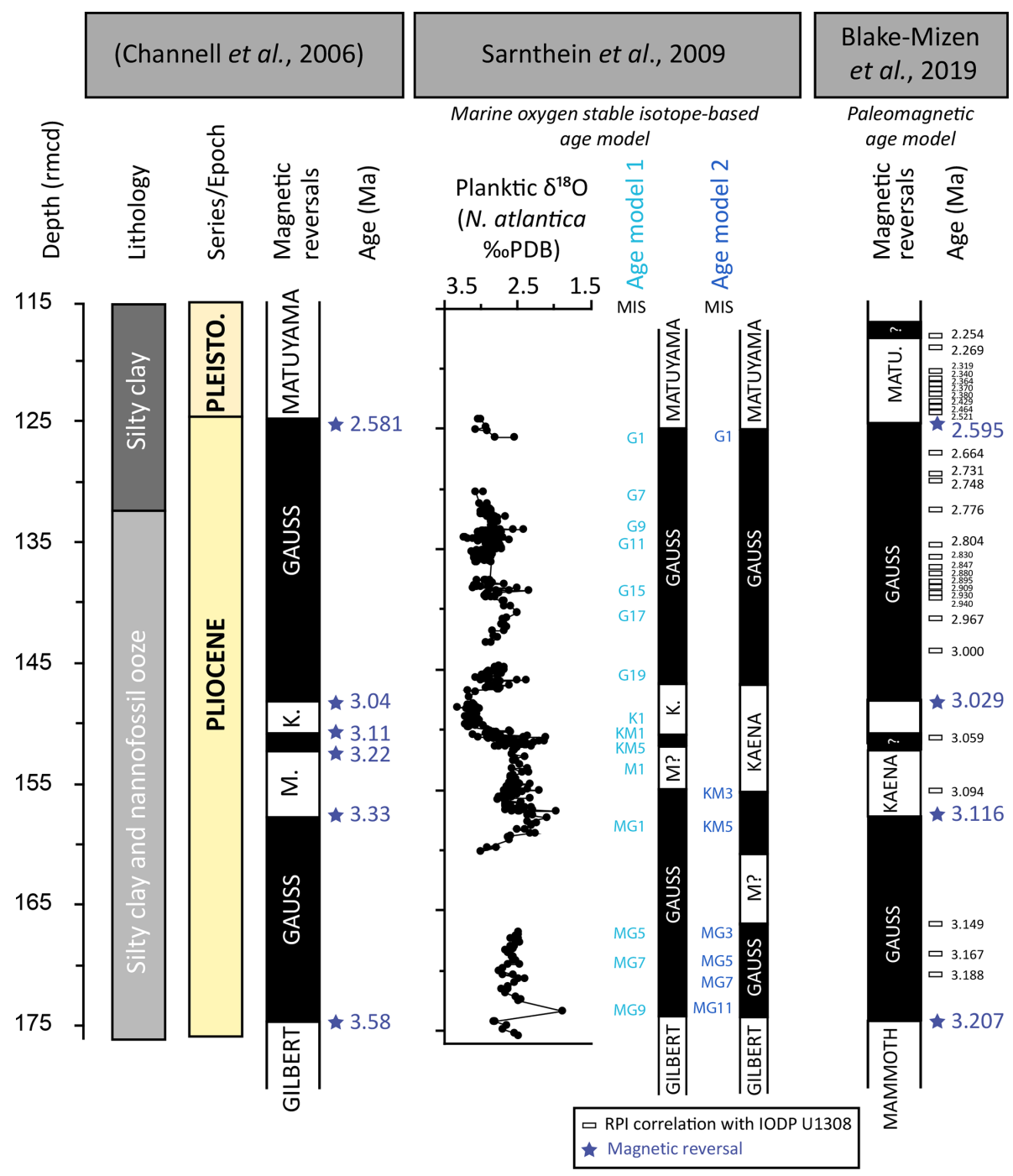

Figure 2. Age models at IODP Site U1307. Magnetostratigraphy and lithology of IODP Site U1307 from Channell et al. (2006). Stable oxygen isotope data based on the planktic foraminifer Neogloboquadrina atlantica and two proposed age models from Sarnthein et al. (2009). The most recent age model is based on magnetic reversals and a paleointensity record tuned to IODP Site U1308 (Blake-Mizen et al., 2019). M: Mammoth Subchron; K: Kaena Subchron; MIS: Marine Isotope Stage; RPI: relative paleointensity.

U1307 before $\sim 2.9 \mathrm{Ma}$. A sedimentary change recorded between 2.9 and $2.7 \mathrm{Ma}$ was interpreted as a change in the depth of the flow path of the WBUC relative to the site (BlakeMizen et al., 2019). Although assessment on the strength of the WBUC remains equivocal, the change in sedimentary regime implies possibly variation in lateral transport from $\sim 2.9$ to $2.7 \mathrm{Ma}$. Hence, taphonomical processes cannot be discarded as an important factor of the palynological signal at our study site as elsewhere in the ocean (Nooteboom et al., 2019). As lateral transport would follow the route of the EGC and WBUC, an upstream origin of small-sized particles is possible, and our record could represent fluxes from along the southern or southeastern Greenland margins (see also: https://planktondrift.org, last access: 21 February 2020).

\section{Results}

\subsection{General}

In the 178 analyzed samples, organic palynomorphs are well preserved. Dinocysts and acritarchs dominate the palynomorph assemblages, but freshwater algae, pollen grains and spores, and reworked marine and terrestrial palynomorphs are also common. Dinocysts occur in all samples and only three samples contain less than 10 cysts per slide. Two samples have been discarded because of mislabeling (\#13C316 and \#13C317). Concentrations range from 27 to 3126 cysts $^{-1}$ of dry sediment with an average of 442 cysts $g^{-1}$ of dry sediment. Acritarch concentrations are higher with an average of 1352 acritarchs g $^{-1}$ of 


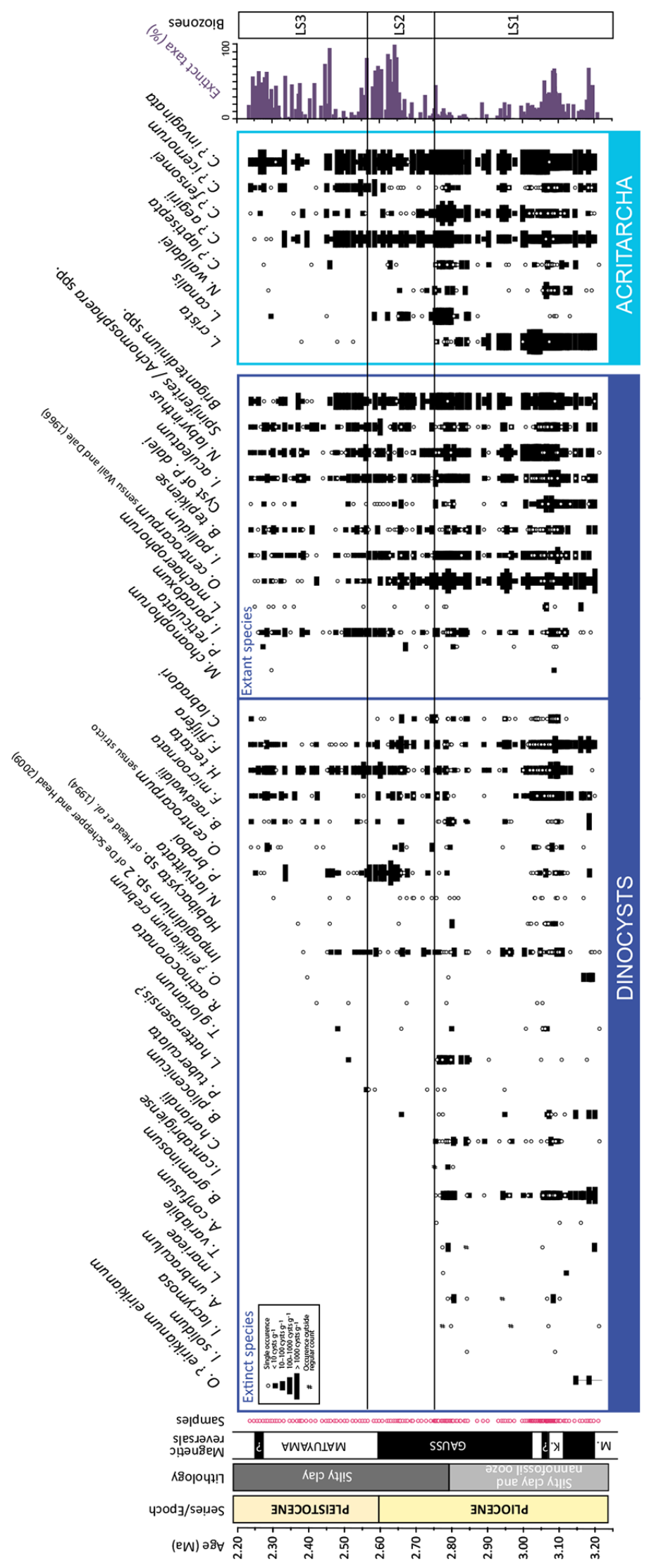

Figure 3. IODP Site U1307 stratigraphic occurrence of selected dinocyst and acritarch taxa and biozones defined in this study, calibrated against the Blake-Mizen et al. (2019) age model. All raw data are available in Data S2. 
Table 1. Age model tie points used at IODP Site U1307 from Blake-Mizen et al. (2019). Magnetostratigraphic reversals are in bold.

\begin{tabular}{|c|c|c|c|c|c|c|c|}
\hline \multirow[t]{2}{*}{$\begin{array}{l}\text { Depth } \\
\text { (rmcd) }\end{array}$} & \multirow[t]{2}{*}{ Age (Ma) } & \multirow[t]{2}{*}{ Type } & \multirow[t]{2}{*}{ Chronology } & \multicolumn{2}{|c|}{$\begin{array}{c}\text { Upper } \\
\text { boundary }\end{array}$} & \multicolumn{2}{|c|}{$\begin{array}{c}\text { Lower } \\
\text { boundary }\end{array}$} \\
\hline & & & & sample & depth (rmcd) & sample & depth (rmcd) \\
\hline 117.63 & 2.25384 & RPI & U1308 & & & & \\
\hline 118.51 & 2.2687 & RPI & U1308 & & & & \\
\hline 120.52 & 2.31938 & RPI & U1308 & & & & \\
\hline 121.3 & 2.34027 & RPI & U1308 & & & & \\
\hline 121.86 & 2.3642 & RPI & U1308 & & & & \\
\hline 122.05 & 2.37048 & RPI & U1308 & & & & \\
\hline 122.4 & 2.38028 & RPI & U1308 & & & & \\
\hline 123.11 & 2.42918 & RPI & U1308 & & & & \\
\hline 123.53 & 2.46437 & RPI & U1308 & & & & \\
\hline 123.96 & 2.52141 & RPI & U1308 & & & & \\
\hline 124.88 & 2.595 & Reversal & $\begin{array}{l}\text { Gauss- } \\
\text { Matuyama }\end{array}$ & $\begin{array}{l}U 1307 A-14 H-3 \\
143 \mathrm{~cm}\end{array}$ & 124.74 & $\begin{array}{l}\text { U1307A-14H-4 } \\
25 \mathrm{~cm}\end{array}$ & 125.06 \\
\hline 127.32 & 2.66445 & RPI & U1308 & & & & \\
\hline 129.1 & 2.73077 & RPI & U1308 & & & & \\
\hline 129.73 & 2.74782 & RPI & U1308 & & & & \\
\hline 132 & 2.77611 & RPI & U1308 & & & & \\
\hline 135 & 2.80408 & RPI & U1308 & & & & \\
\hline 136.03 & 2.82958 & RPI & U1308 & & & & \\
\hline 136.86 & 2.84671 & RPI & U1308 & & & & \\
\hline 137.47 & 2.88009 & RPI & U1308 & & & & \\
\hline 138.13 & 2.89464 & RPI & U1308 & & & & \\
\hline 138.54 & 2.90858 & RPI & U1308 & & & & \\
\hline 138.8 & 2.93008 & RPI & U1308 & & & & \\
\hline 139.31 & 2.94014 & RPI & U1308 & & & & \\
\hline 141.12 & 2.96667 & RPI & U1308 & & & & \\
\hline 143.76 & 3.00041 & RPI & U1308 & & & & \\
\hline 147.97 & 3.029 & Reversal & Kaena $(t)$ & $\begin{array}{l}\text { U1307A-17H-2 } \\
61 \mathrm{~cm}\end{array}$ & 147.81 & $\begin{array}{l}\text { U1307A-17H-2 } \\
97 \mathrm{~cm}\end{array}$ & 148.17 \\
\hline 151.01 & 3.05942 & RPI & U1308 & & & & \\
\hline 155.41 & 3.09399 & RPI & U1308 & & & & \\
\hline 157.33 & 3.116 & Reversal & Kaena (b) & $\begin{array}{l}\text { U1307A-18H-2 } \\
31 \mathrm{~cm}\end{array}$ & 157.06 & $\begin{array}{l}\text { U1307A-18H-2 } \\
82 \mathrm{~cm}\end{array}$ & 157.57 \\
\hline 166.48 & 3.14918 & RPI & U1308 & & & & \\
\hline 168.96 & 3.16734 & RPI & U1308 & & & & \\
\hline 170.7 & 3.18776 & RPI & U1308 & & & & \\
\hline 174.48 & 3.207 & Reversal & Mammoth (t) & $\begin{array}{l}U 1307 A-19 H-6 \\
60 \mathrm{~cm}\end{array}$ & 173.93 & $\begin{array}{l}\text { U1307A-19H-6 } \\
120 \mathrm{~cm}\end{array}$ & 174.53 \\
\hline
\end{tabular}

dry sediment and a maximum value of 8975 acritarchs $\mathrm{g}^{-1}$ of dry sediment. Terrestrial palynomorphs (pollen and spores) are less abundant. Among samples analyzed, 10 yielded less than 10 terrestrial palynomorphs per slides. They are nevertheless common with concentrations ranging up to 1209 palynomorphs $\mathrm{g}^{-1}$ of dry sediment (average of 262 palynomorphs $\mathrm{g}^{-1}$ of dry sediment). Freshwater algae occur occasionally, with a maximum value of 106 algae $\mathrm{g}^{-1}$ of dry sediment and an average of 11 algae $^{-1}$ of dry sediment.

The number of dinocyst species is high with 115 taxa identified, among which 43 are extinct today. The number of taxa ranges from 4 to 26 per sample with an average of 14. The two most dominant taxa are Operculo- dinium centrocarpum sensu Wall and Dale (1966) (Operculodinium centrocarpum hereafter) and the round brown cysts group. Round brown cysts combine all sub-spherical brown protoperidinoid cysts without processes and with or without a visible archeopyle (for example they include all cysts of Brigantedinium). In addition, the other dominant taxa are Nematosphaeropsis labyrinthus, Impagidinium aculeatum, Habibacysta tectata, Filisphaera filifera, Impagidinium pallidum, Filisphaera microornata, cysts of Pentapharsodinium dalei, Spiniferites/Achomosphaera spp., Bitectatodinium tepikiense and Impagidinium paradoxum.

Acritarchs dominate the marine assemblages comprising up to $96 \%$ of some, with an average of $63 \%$. A total of 
24 taxa were recorded. Common to abundant species include Cymatiosphaera? invaginata, Cymatiosphaera? fensomei, Cymatiosphaera? aegirii, Cymatiosphaera? icenorum, Lavradosphaera crista and Lavradosphaera canalis. Sphaeromorph acritarchs are also abundant and globally correspond to discoidal to spherical forms as illustrated in Schreck et al. (2013).

\subsection{Age calibration of selected bioevents}

We have identified biostratigraphic events as described in De Schepper and Head (2008b). The highest occurrence (HO) is the last sample with the presence of a given taxon, and, conversely, the lowest occurrence (LO) is the first sample with the occurrence of a taxon. The highest persistent occurrence (HPO) is the highest successive occurrence of a species, even in low abundance, and sporadic occurrence after the HPO might be reworked specimens. The highest common occurrence (HCO) is the highest notable and abundant occurrence of a taxon, which can still occur higher up in the record but then in lower numbers.

Calibrated ages for dinocyst and acritarch HO, LO, HPO and HCO are summarized in Table 2. Standard zonations of calcareous nannofossils (Martini, 1971), planktonic foraminifers (Berggren et al., 1985, 1995) and diatoms (Baldauf, 1987; Baldauf et al., 1989), as well as the relevant Pliocene and Pleistocene ATNTS2012 polarity chrons (Hilgen et al. 2012).

\subsection{Biostratigraphy and biozonation}

Our Labrador Sea biozonation is the first high-resolution biostratigraphy of the Neogene to Quaternary for the Labrador Sea. It has been made to better document the biostratigraphy of the Plio-Pleistocene transition in this region in order to lay foundations for future regional and supraregional correlations with other records from the North Atlantic and Arctic oceans. It has been suggested that bioevents recorded during the Neogene-Quaternary primarily represent a response to ecological stresses due to climatic changes rather than evolutionary features (De Schepper and Head, 2008b; Schreck et al., 2012, 2013; De Schepper et al., 2015). However, some dinocysts and acritarchs have stratigraphically well-defined ranges. This is the case for Habibacysta tectata and Filisphaera filifera, which have been used for supra-regional stratigraphic correlation between the Arctic Ocean and adjacent basins (Matthiessen et al., 2018) and the acritarch genera Lavradosphaera and Cymatiosphaera that also seem to have a stratigraphical range allowing correlations at midlatitudes to high latitudes of the Northern Hemisphere (De Schepper and Head, 2014; this study).

The biozonation we developed here follows the nomenclature of the International Stratigraphic Guide (abridged version of Murphy and Salvador, 1999). Accordingly, the zones are defined as assemblage (LS1, LS3) and abundance (acme) biozones (LS2).

Zone boundaries are defined from bioevents, which occur almost synchronously across the high-latitude North Atlantic including the Labrador Sea. These bioevents include the HO of Barssidinium graminosum and the acme of Pyxidinopsis braboi (Figs. 3, 4; Table 2). Most dinocyst and acritarch taxa used as stratigraphic markers in the study are illustrated in Plates S1 and S2 in the Supplement. The biozones have been given informal names (LS1 to LS3) in reference to the location of IODP Site U1307 in the Labrador Sea. Dinocyst and acritarch taxa in each zone are described based on their relative abundances: rare $(1 \%-3 \%)$, frequent $(3 \%-10 \%)$, common (10\%-30\%), abundant (30\%-50\%) and dominant $(>50 \%)$.

\section{LS1 Barssidinium graminosum Assemblage Zone}

\section{Definition}

This zone is characterized by the association of the almostcontinuous occurrence of Barssidinium graminosum, Lavradosphaera crista and Corrudinium harlandii. It spans from the base of the studied interval to the HO of Barssidinium graminosum.

\section{Other bioevents}

Operculodinium? eirikianum eirikianum and Operculodinium? eirikianum crebrum have limited occurrences restricted from the base of the zone to 167.61 and $169.63 \mathrm{rmcd}$, respectively.

At the top of zone LS1, the HPO of Lavradosphaera crista occurs at $130.00 \mathrm{rmcd}$. Near the top of zone LS1, the HPO of Lejeunecysta hatterasensis occurs between 134.15 and $130.80 \mathrm{rmcd}$; an acme of the acritarch Cymatiosphaera? fensomei occurs at 136.80-130.80 rmcd and the $\mathrm{HCO}$ of Lavradosphaera canalis occurs at $\sim 130.00 \mathrm{rmcd}$. The lowest common occurrence of Lavradosphaera canalis occurs at $136.50 \mathrm{rmcd}$.

\section{Reference section}

Samples U1307A-19H07, 28-30 cm, to U1307B-14H03, 30$32 \mathrm{~cm}$, or from 175.11 to $130.00 \mathrm{rmcd}$.

Age

Late Pliocene, from > 3.21 to $2.75 \mathrm{Ma}$.

\section{Calibration}

Calcareous nannofossil zone NN16, planktonic foraminifer zone N20-21 and Nitzschia jouseae diatom zone, and they correspond to subchron C2An.2n, C2An.1r and C2An.1n. 
Table 2. Dinocyst and acritarch bioevents at IODP Site U1307. The age model error is from Blake-Mizen et al. (2019) and the age error is based on the sampling interval. HO: highest occurrence; HCO: highest common occurrence; HPO: highest persistent occurrence.

\begin{tabular}{|c|c|c|c|c|c|}
\hline Event & Species & Sample & Depth (rmcd) & Age (Ma) & Error $(\mathrm{Ma})$ \\
\hline \multicolumn{6}{|l|}{ Dinocysts } \\
\hline $\mathrm{HO}$ & Melitasphaeridium choanophorum & U1307B-13H03, 57.5-59.5 cm & 119.40 & 2.29 & 0.0068 \\
\hline $\mathrm{HO}$ & $\begin{array}{l}\text { Impagidinium sp. } 2 \text { of } \\
\text { De Schepper and Head (2009) }\end{array}$ & U1307A-14H02, 60-62 cm & 122.41 & 2.38 & 0.0041 \\
\hline $\mathrm{HO}$ & Lejeunecysta hatterasensis & $\mathrm{U} 1307 \mathrm{~A}-14 \mathrm{H} 03,54-56 \mathrm{~cm}$ & 123.85 & 2.51 & 0.0079 \\
\hline $\mathrm{HO}$ & Pyxidinopsis tuberculata & U1307A-14H03, 110-112 cm & 124.41 & 2.56 & 0.008 \\
\hline Acme (top) & Pyxidinopsis braboi & U1307A-14H03, 120-122 cm & 124.51 & 2.57 & 0.008 \\
\hline Acme (bottom) & Pyxidinopsis braboi & $\mathrm{U} 1307 \mathrm{~B}-13 \mathrm{H} 07,55-57 \mathrm{~cm}$ & 126.75 & 2.65 & 0.0057 \\
\hline $\mathrm{HO}$ & Barssidinium pliocenicum & U1307B-14H01, 30-32 cm & 127.00 & 2.66 & 0.0028 \\
\hline $\mathrm{HO}$ & Corrudinium harlandii & $\mathrm{U} 1307 \mathrm{~B}-14 \mathrm{H} 03,28-33 \mathrm{~cm}$ & 129.98 & 2.75 & 0.0093 \\
\hline $\mathrm{HO}$ & Barssidinium graminosum & $\mathrm{U} 1307 \mathrm{~B}-14 \mathrm{H} 03,30-32 \mathrm{~cm}$ & 130.00 & 2.75 & 0.0003 \\
\hline $\mathrm{HO}$ & Ataxiodinium confusum & $\mathrm{U} 1307 \mathrm{~B}-14 \mathrm{H} 03,50-52 \mathrm{~cm}$ & 130.20 & 2.75 & 0.0025 \\
\hline $\mathrm{HPO}$ & Lejeunecysta hatterasensis & $\mathrm{U} 1307 \mathrm{~B}-14 \mathrm{H} 03,110-112 \mathrm{~cm}$ & 130.80 & 2.76 & 0.0038 \\
\hline $\mathrm{HO}$ & Invertocysta lacrymosa & U1307B-14H05, 130-132 cm & 134.01 & 2.79 & 0.0046 \\
\hline $\mathrm{HO}$ & Impagidinium solidum & U1307B-15H01, 50-52 cm & 136.50 & 2.84 & 0.0041 \\
\hline $\mathrm{HO}$ & Operculodinium? eirikianum eirikianum & U1307A-19H02, 28-30 cm & 167.61 & 3.16 & 0.014 \\
\hline HPO & Operculodinium? eirikianum crebrum & U1307A-19H03, 80-82 cm & 170.63 & 3.19 & 0.0103 \\
\hline \multicolumn{6}{|l|}{ Acritarchs } \\
\hline $\mathrm{HPO}$ & Cymatiosphaera? aegirii & U1307B-13H04, 52-54 cm & 120.85 & 2.33 & 0.0067 \\
\hline HPO & Lavradosphaera canalis & U1307B-14H03, 140-142 cm & 124.71 & 2.58 & 0.0043 \\
\hline $\mathrm{HCO}$ & Lavradosphaera canalis & U1307B-14H03, 30-32 cm & 130.00 & 2.75 & 0.0003 \\
\hline $\mathrm{HPO}$ & Lavradosphaera crista & U1307B-14H03, 50-52 cm & 130.20 & 2.75 & 0.0253 \\
\hline Acme (top) & Cymatiosphaera? fensomei & U1307B-14H03, 110-112 cm & 130.80 & 2.76 & 0.0038 \\
\hline Acme (bottom) & Cymatiosphaera? fensomei & U1307B-15H01, 80-82 cm & 136.80 & 2.85 & 0.0062 \\
\hline $\mathrm{HCO}$ & Lavradosphaera crista & U1307B-15H02, 80-82 cm & 138.30 & 2.90 & 0.0078 \\
\hline
\end{tabular}

\section{Correlation}

The top of zone LS1 coincides with the top of the Invertocysta lacrymosa Interval Zone or RT5 zone at DSDP 610A placed at 2.74 Ma (De Schepper and Head, 2008b).

\section{Dinocyst association}

Dominant to rare: round brown cysts: Operculodinium centrocarpum, Filisphaera filifera and Nematosphaeropsis labyrinthus. Abundant to rare: Impagidinium aculeatum and Habibacysta tectata. Common to rare: Impagidinium paradoxum, Spiniferites/Achomosphaera spp., Bitectatodinium tepikiense/Filisphaera microornata, Impagidinium pallidum, Pyxidinopsis braboi and cysts of Pentapharsodinium dalei. Rare: Impagidinium sp. 2 of De Schepper and Head, 2009, and Corrudinium? labradori.

\section{Acritarch association}

Dominant to abundant acritarchs: Cymatiosphaera? invaginata. Dominant to common: Lavradosphaera crista. Abundant to rare: Cymatiosphaera? fensomei. Common to rare: Cymatiosphaera? aegirii. Frequent to rare: Cymatiosphaera? icernorum. Rare: Cymatiosphaera latisepta.

\section{LS2 Pyxidinopsis braboi Abundance Zone}

Definition

The body of strata from the $\mathrm{HO}$ of Barssidinium graminosum to the top of the acme of Pyxidinopsis braboi.

\section{Other events}

The HPO of Lavradosphaera canalis (124.71 rmcd) occurs near the top of the zone.

\section{Reference section}

Samples U1307B-14H03, 28-30 cm, to U1307A 14H03, $120-122 \mathrm{~cm}$, or from 130.00 to $124.51 \mathrm{rmcd}$.

Age

Late Pliocene to Early Pleistocene, from 2.75 to $2.57 \mathrm{Ma}$.

\section{Calibration}

Upper calcareous nannofossil zone NN16, planktonic foraminifer zone N20-21, upper Nitzschia jouseae diatom 
zone and the uppermost part of subchron C2An.1n to C2r.2r. The top of the zone broadly corresponds to the GaussMatuyama reversal and the Plio-Pleistocene boundary.

\section{Correlation}

Zone LS2 correlates well with zone RT6 at DSDP Hole 610A of De Schepper and Head (2009) in the eastern North Atlantic. The $\mathrm{HO}$ of Barssidinium graminosum defines the base of zone RT6, which is placed at 2.74-2.69 Ma. The Pyxidinopsis braboi acme was missed by De Schepper and Head (2009) probably because of a $2.1 \mathrm{~m}$ sample gap between 126.37 and $128.47 \mathrm{~m}$ b.s.f. Hennissen et al. (2014) covered this interval in more detail and recorded the Pyxidinopsis braboi acme between 127.55 and $128.21 \mathrm{~m}$ b.s.f. (2.592.61 Ma, corresponding to MIS 104), at the boundary between zones RT6 and RT7 as defined by De Schepper and Head (2009).

\section{Dinocyst association}

Dominant to rare: round brown cysts: Operculodinium centrocarpum. Abundant to rare: Impagidinium aculeatum and Habibacysta tectata. Common to rare: Impagidinium pallidum, Nematosphaeropsis labyrinthus, Impagidinium paradoxum, Spiniferites/Achomosphaera, Bitectatodinium tepikiense and Filisphaera microornata. Rare: Corrudinium? labradori and Impagidinium sp. 2 of De Schepper and Head, 2009.

\section{Acritarch association}

Dominant to frequent acritarchs: Cymatiosphaera? invaginata. Dominant to rare: Cymatiosphaera? aegirii. Frequent to rare: Lavradosphaera canalis. Rare and sporadic: Cymatiosphaera? fensomei and Cymatiosphaera? icenorum.

\section{LS3 Habibacysta tectata Assemblage Zone}

\section{Definition}

The body of strata from the acme of Pyxidinopsis braboi to the top of the studied interval. The zone is characterized by the association of Habibacysta tectata, Filisphaera filifera, and Filisphaera microornata and Bitectatodinium tepikiense.

\section{Other events}

HPOs of Cymatiosphaera? aegirii (120.85 rmcd) and Impagidinium sp. 2 of De Schepper and Head, 2009 (122.41 rmcd).

\section{Reference section}

Samples U1307A 14H03, 120-122 cm, to U1307B-13H01, 60-62 cm, or from 124.51 to $116.43 \mathrm{rmcd}$.
Age

Early Pleistocene, from 2.57 to 2.23 Ma.

\section{Calibration}

Calcareous nannofossil zone NN17 and NN18, planktonic foraminifer zone N20-21, latest Nitzschia jouseae and Nitzschia marina diatom zone and subchron C2r.2r. The base of the zone broadly corresponds to the Gauss-Matuyama reversal and the Plio-Pleistocene boundary.

\section{Correlation}

Precise correlation with the eastern North Atlantic zonation is difficult, but the dinocyst association of zone LS3 shows great similarities with zone RT7 characterized by Habibacysta tectata (De Schepper and Head, 2009; Hennissen et al., 2014).

\section{Dinocyst association}

Dominant to rare: round brown cysts. Sporadic occurrence peaks of Pyxidinopsis braboi. Abundant to rare: Impagidinium aculeatum, Spiniferites/Achomosphaera, Bitectatodinium tepikiense, Habibacysta tectata, Nematosphaeropsis labyrinthus and Filisphaera microornata. Common to rare: Impagidinium paradoxum, Impagidinium pallidum, Filisphaera filifera. Frequent to rare: Operculodinium centrocarpum.

\section{Acritarch association}

Dominant to frequent: Cymatiosphaera? invaginata. Dominant to rare: Cymatiosphaera? aegirii. Rare and sporadic: Cymatiosphaera? fensomei. Rare: Cymatiosphaera? icenorum.

\section{Discussion}

\subsection{Comparison with previously established zonation at the nearby ODP Hole 646}

We analyzed 178 samples from the Late Pliocene to Early Pleistocene at intervals ranging between 1 and $400 \mathrm{~cm}(0.1$ and $30 \mathrm{kyr}$ ). Our study focused on the Plio-Pleistocene transition and was made with considerably higher temporal resolution than that of de Vernal and Mudie (1989), who investigated 155 samples at $1.5 \mathrm{~m}$ intervals in the Pliocene to Holocene sediments recovered at ODP Hole 646B. The pioneering work of de Vernal and Mudie (1989) identified a rich palynological assemblage, including several new taxa characteristics of the Pliocene that were left in open nomenclature. The knowledge of the North Atlantic Neogene dinocyst and acritarchs has improved considerably over the last two decades as several new taxa were described (Head, 1993, 
1996, 1997; Versteegh and Zevenboom, 1995; Head and Norris, 2003; De Schepper et al., 2004; De Schepper and Head, 2008a, 2014; Schreck et al., 2012; Verhoeven et al., 2014). Using the state-of-the-art taxonomy, we identified 115 dinocyst and 24 acritarch taxa at Site U1307, which represents a much higher species diversity than the one reported by de Vernal and Mudie (1989) which reported $\sim 51$ dinocyst and $\sim 8$ acritarch taxa at ODP Hole 646B.

Five intervals were defined by de Vernal and Mudie (1989). The interval V $(\sim 5.4-4.8 \mathrm{Ma})$ is based on the occurrence of the dominant taxa: Brigantedinium spp., Nematosphaeropsis labyrinthus (as Nematosphaeropsis labyrinthea), Filisphaera filifera, Cymatiosphaera? invaginata (as Cymatiosphaera sp. I) and Batiacasphaera sphaerica; Interval IV ( 4.8-4.0 Ma) is defined by the stratigraphic range and abundance of cyst type 1; Interval III (4-2.3 Ma) is distinguished by the common-to-abundant occurrence of Lavradosphaera crista (as Incertae sedis I). The base of Interval II $(\sim 2.36-\sim 1.23 \mathrm{Ma})$ corresponds to the common occurrence of Cymatiosphaera latisepta (as Nematosphaeropsis sp. I) and Pyxidinopsis braboi (as Tectatodinium sp. II) and the top corresponds to the HOs of Filisphaera filifera and Cymatiosphaera? invaginata. Finally, Interval I $(\sim 1.2-$ $0 \mathrm{Ma}$ ) is characterized by modern dinocyst species common in the Labrador Sea such as Operculodinium centrocarpum, Nematosphaeropsis labyrinthus and Brigantedinum spp.

The comparison of the biostratigraphical schemes is hampered by the temporal resolution and the definition of the biozones and their boundaries in the different studies. While de Vernal and Mudie (1989) defined biozones using abundances of dinocyst and acritarch, we used bioevents such as HOs and acme to define our biozone limits. Nevertheless, our zones LS1, LS2 and the majority of LS3 correspond generally to Interval III of de Vernal and Mudie (1989) (Fig. 4). Their Interval III is characterized by common to abundant occurrence of Lavradosphaera crista, and the top of this interval corresponds to the last record of this acritarch in IODP Site U1307 at $2.38 \mathrm{Ma}$. Interval III is also defined by the dominance of the acritarchs Cymatiosphaera? invaginata and Lavradosphaera crista accompanied with the dinocysts Brigantedinium spp., Filisphaera filifera, $\mathrm{Ne}$ matosphaeropsis labyrinthus and Operculodinium centrocarpum. We also identified these species throughout our study interval at IODP Site U1307 as an important part in the dinocyst assemblage. However, the lower part of Interval III does not have overlap with our biozonation. It is characterized by the last common occurrence of Operculodinium? eirikianum (as Operculodinium longispinigerum in de Vernal and Mudie, 1989). At IODP Site U1307, both subspecies Operculodinium? eirikianum var. crebrum and Operculodinium? eirikianum var. eirikianum occur at the base of zone LS1, which thus extend their stratigraphic range in the Labrador Sea.

The uppermost part of zone LS3 corresponds to the lowest part of Interval II (Fig. 4). The base of Interval II was de- fined based on common occurrence of Cymatiosphaera latisepta (as Nematosphaeropsis sp. I in de Vernal and Mudie, 1989) and Pyxidinopsis braboi of which the end of the acme marked the base of zone LS3.

\subsection{Comparison with the North Atlantic Ocean and the adjacent seas}

\subsubsection{Restricted time resolution}

The comparison of our new dinocyst and acritarch zonation for the Labrador Sea with the palynostratigraphy of other regions is difficult. The time interval and resolution of the biostratigraphic record differ from site to site, and our study interval (3.2-2.2 Ma) is often poorly represented in previously published zonations (see Fig. 4). Our study interval is situated in the Melitasphaeridium choanophorum zone of Williams and Bujak (1977) from offshore eastern Canada, Zone III of Harland (1979) defined from DSDP 400 in Bay of Biscay, Zone II of Mudie (1987) at DSDP Sites 607 and 611 in the North Atlantic, and in the PM2 Filisphaera filifera acme zone at ODP Sites 642, 643 and 644 in the Norwegian Sea (Mudie, 1989). Only two studies reporting data with a temporal resolution highlighting boundaries within our studied time interval allow a comparison with our record; one is from the Danish North Sea onshore-offshore well section compilation of Dybkjær and Piasecki (2010), and the other is from the North Atlantic DSDP Hole 610A (De Schepper and Head, 2009) (Fig. 4).

\subsubsection{Absence of Pliocene stratigraphic marker species in the Labrador Sea}

Despite the relatively high temporal resolution of our analyses, the occurrence of indicator taxa used in the Neogene biostratigraphy of the North Atlantic is rare and discontinuous. The indicator taxa include Impagidinium solidum, Ataxiodinium confusum and Invertocysta lacrymosa, which occur occasionally making them unsuitable for robust biostratigraphic assessment at IODP Site U1307 (see Fig. 4).

The top of zone RT4 in the North Atlantic DSDP Hole $610 \mathrm{~A}$ is defined by the HO of Impagidinium solidum at 3.25 Ma (De Schepper et al., 2009). This species, which has not been recorded in the Labrador Sea by de Vernal and Mudie (1989), is identified in only two samples as single occurrences in our study (Figs. 3, 4). Ataxiodinium confusum seems to disappear at the end of the Pliocene around $2.6 \mathrm{Ma}$ across the North Atlantic (De Schepper and Head, 2008b, 2009; Hennissen et al., 2014). In our Labrador Sea record, Ataxiodinium confusum has three single occurrences before $2.75 \mathrm{Ma}$ (Fig. 4). The HO of Invertocysta lacrymosa that characterizes the top of zone RT5 in DSDP Hole 610A (2.72 Ma; De Schepper et al., 2009) is a widespread bioevent during the iNHG across the midlatitudes in the North Atlantic Ocean; in the Bay of Biscay, it occurred at $2.84 \mathrm{Ma}$ (Harland, 1979); in the central North Atlantic DSDP Site 


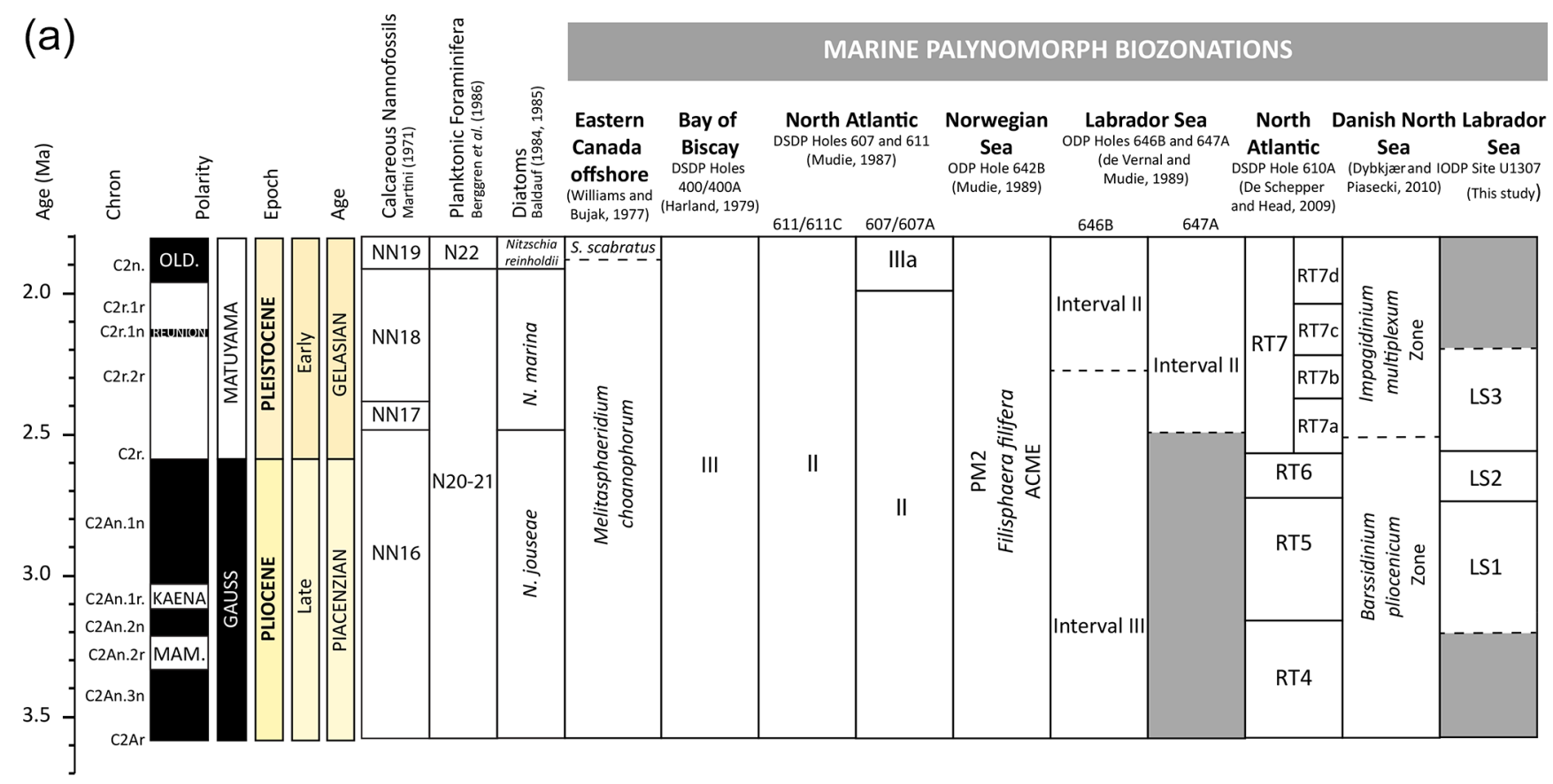

(b)

\section{CALIBRATED STRATIGRAPHIC RANGE OF SELECTED DINOCYST SPECIES}

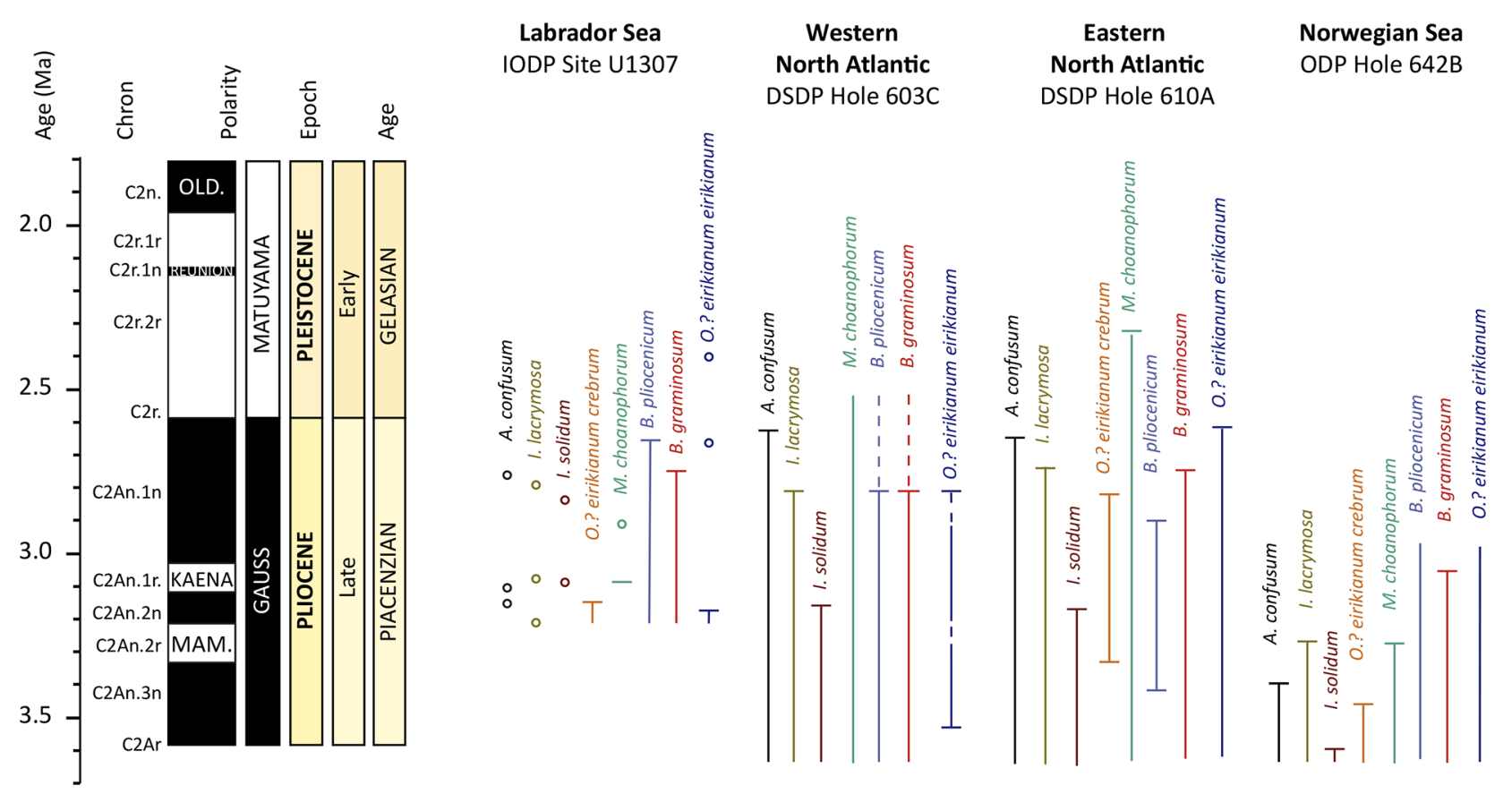

Figure 4. (a) Late Pliocene-Early Pleistocene dinocyst biozonation schemes from different locations in the North Atlantic. (b) Adapted from De Schepper et al. (2017). Late Pliocene dinocyst extinction events in the Labrador Sea (this study), the western North Atlantic (DSDP Hole 603C; Head and Norris, 2003; Martin J. Head, unpublished data), eastern North Atlantic (DSDP Hole 610A; De Schepper and Head, 2008a, b, 2009) and the Norwegian Sea (ODP Hole 642B; De Schepper et al., 2015, 2017). 
607/607A and the Singa section of southern Italy, it occurred at $2.74 \mathrm{Ma}$ (Versteegh, 1997); in the western North Atlantic DSDP Hole 603C it occurred at 2.81 Ma (Martin J. Head, unpublished data in De Schepper and Head, 2008b), in Hole U1313C, at 2.74 Ma (Hennissen et al., 2014). Its HO occurs around 2.79 Ma at IODP Site U1307, which is consistent with other North Atlantic records, but was found only in three samples as a single specimen.

Other taxa that could be used as stratigraphical markers are conspicuously present in our study interval and have a continuous range of occurrence with marked HOs. These taxa include Barssidinium graminosum, Lavradosphaera crista and Lavradosphaera canalis (Figs. 3, 4 and 5). Barssidinium species are used in both biostratigraphical schemes of the Danish North Sea onshore-offshore well section compilation of Dybkjær and Piasecki (2010) and the North Atlantic DSDP Hole 610A of De Schepper and Head (2009). In the scheme of Dybkjær and Piasecki (2010) the boundary between the Barssidinium pliocenicum zone and the Impagidinium multiplexum zone, defined at 2.4-2.6 Ma, encompasses our LS2-LS3 limit at 2.57 Ma (Fig. 4). This boundary is based on the HO of Barssidinium pliocenicum and the LO of Impagidinium multiplexum, followed by the LO of Bitectatodinium tepikiense. At IODP Site U1307, Impagidinium multiplexum is not recorded; Bitectatodinium tepikiense is common throughout the interval studied (3.2-2.2 Ma), but Barssidinium pliocenicum is found until 2.66 Ma (Fig. 3). Specimens of Barssidinium pliocenicum were identified in younger sediments of southwest England ( 2.1-1.95 Ma; Head, 1993), the North Sea (2.4-1.8 Ma; Head et al., 2004), ODP Site 986 on the Svalbard-Barents shelf (up to $2.17 \mathrm{Ma}$; Smelror, 1999; Knies et al., 2009) and northern Iceland (> $2 \mathrm{Ma}$; Verhoeven et al., 2011, and references therein). At other North Atlantic sites, the HO of Barssidinium pliocenicum is older. It occurs around 2.75 Ma in ODP Hole 603C (Martin J. Head, unpublished data) and around 2.72 Ma in DSDP Hole 610A (De Schepper, 2006). The HO of Barssidinium pliocenicum seems therefore diachronous across the North Atlantic. On the contrary, the HO of Barssidinium graminosum that we use to define the top of zone LS1 seems to occur simultaneously in the Labrador Sea $(2.75 \mathrm{Ma})$, the western North Atlantic (DSDP Hole 603C; 2.77-2.76 Ma; Martin J. Head, unpublished data) and the eastern North Atlantic (DSDP Hole 610A; 2.74 Ma; De Schepper and Head, 2008b) (Fig. 4).

\subsubsection{Regional paleoceanographic conditions overprinting the biostratigraphy}

While most sites used with a Late Neogene stratigraphical scheme are under the influence of warm North Atlantic waters, IODP Site U1307 is situated in the path of the East Greenland Current, which carries relatively fresh and cool waters (Fig. 1). Ocean circulation and distribution of water masses have played an important role in the geographical oc- currences of Neogene species such as Impagidinium solidum, Ataxiodinium confusum, Invertocysta lacrymosa and Melitasphaeridium choanophorum, and are likely causing asynchronous bioevents. This hampers biostratigraphic correlations throughout the Labrador Sea and North Atlantic.

Impagidinium solidum and Ataxiodinium confusum have preference for warmer waters (De Schepper et al., 2011; Hennissen et al., 2017), and their low abundance during the Late Pliocene in the Labrador Sea may indicate cooler waters than those in the eastern North Atlantic, where they persisted in younger sediments. In the Norwegian Sea, De Schepper et al. (2017) also found rare occurrences of Impagidinium solidum but restricted to the Early Pliocene until 3.59 Ma. The bioevents of both species in the Norwegian Sea, North Atlantic and Labrador Sea are thus diachronous. Hennissen et al. (2017) interpreted Invertocysta lacrymosa as a warmwater species typical of open oceanic conditions. Also there, low occurrences of Invertocysta lacrymosa in the Labrador Sea and its early HOs in the Norwegian Sea (3.27 Ma; De Schepper et al., 2017) and the Iceland Sea (4.45 Ma; Schreck et al., 2012) during the Early Pliocene support cooler conditions in the northern part of the North Atlantic Ocean, than at midlatitudes.

The low abundance of Melitasphaeridium choanophorum in only two samples before $2.29 \mathrm{Ma}$ at our study site contrasts with the persistent rare to common record in DSDP Hole 610A until 2.98 Ma (De Schepper, 2006). This species is considered typical of the Pliocene across the North Atlantic Ocean (Williams and Bujak, 1977; De Schepper and Head, 2009; Dybkjær and Piasecki, 2010; De Schepper et al., 2017). But the occurrence of Melitasphaeridium choanophorum in the western North Atlantic in DSDP Hole 603C through the Pliocene and Early Pleistocene (Martin J. Head, unpublished data in De Schepper et al., 2017), on the Scotian Shelf and Grand Banks in the Pliocene and the Late Gelasian (Williams and Bujak, 1977), and even in recent sediments of the Gulf of Mexico (Limoges et al., 2013, 2014; Price et al., 2017) indicates a more extended range than previously thought and affinities for subtropical conditions. Its diachronous disappearance from the Pliocene North Atlantic and persistence in the Gulf of Mexico may be related to cooling and the intensification of glaciation during the Quaternary.

At DSDP 610A, the top of zone RT6 dated at $2.62 \mathrm{Ma}$ corresponds to the $\mathrm{HO}$ of Operculodinium? eirikianum var. eirikianum. However, at IODP Site U1307 both subspecies Operculodinium? eirikianum var. eirikianum and Operculodinium? eirikianum var. crebrum are restricted to the beginning of zone LS1 with HOs around 3.18-3.16 Ma. $O p$ erculodinium? eirikianum is a cool-intolerant species that prefers warmer waters (De Schepper et al., 2015; Hennissen et al., 2017). During the Early Pliocene, this taxon disappeared from the Iceland Sea records, which is interpreted to be a result of regional cooling due to changes in oceanic gateway configuration at the onset of the modern circulation 
in the Nordic Seas and deep ocean circulation in the North Atlantic (De Schepper et al., 2015). Thus, Operculodium? eirikianum has an asynchronous HO across the North Atlantic, the Nordic Seas and the Labrador Sea, possibly due to regional changes and reorganization of ocean circulation.

At IODP Site U1307, we noticed a low abundance but a recurring occurrence of Corrudinium harlandii until $2.76 \mathrm{Ma}$. This species is considered extinct, but it shares morphological similarities with the modern taxon Pyxidinopsis reticulata, notably in the expression of crests. A morphological gradation between the two taxa was reported to occur in DSDP Hole 610A (De Schepper and Head, 2009), with typical Corrudinium harlandii being more frequent during the Pliocene and typical Pyxidinopsis reticulata extending to the Pleistocene. It is thus possible that Corrudinium harlandii and Pyxidinopsis reticulata represent a morphological gradation of a same genotype that evolved naturally or in response to changing environmental conditions. In modern sediments, Pyxidinopsis reticulata is found from equatorial to subpolar waters but with a preference for temperate conditions in the Pacific Ocean (de Vernal and Marret, 2007; de Vernal et al., 2019). The rare and low occurrence of this taxa in the Labrador Sea is consistent with cool conditions. Although no paleoecological affinity is known for Corrudinium harlandii, the rare and low occurrence of transitional morphotypes suggests distinct conditions in the Labrador Sea compared to the eastern North Atlantic.

Finally, in the Labrador Sea, we defined the top of zone LS2 at $2.57 \mathrm{Ma}$ based on the end of the acme of Pyxidinopsis braboi, which is recorded in DSDP Hole 610A at $\sim 2.58 \mathrm{Ma}$, during MIS 104 (Hennissen et al., 2014). Pyxidinopsis braboi is also found in low numbers in sediment of MIS 104 in IODP Hole U1313C ( 2.61-2.59 Ma; Hennissen et al., 2014). This species is interpreted as a cold, polar, opportunistic taxa (Warny et al., 2009; Hennissen et al., 2014, 2017), and its acme is suggested to result from the Arctic front moving south, close to the DSDP Hole 610A position in the North Atlantic at the Plio-Pleistocene boundary (Hennissen et al., 2014, 2017). Thus, its acme at IODP Site U1307 may provide evidence for increasingly cool conditions and freshwater transport via the EGC into the Labrador Sea at the Plio-Pleistocene transition. However, there are several samples above the Plio-Pleistocene transition that record very few dinocysts, clearly indicating changes in environmental conditions, which may have blurred the stratigraphic range of the different taxa (see Data S2).

\subsection{Paleoceanographic and paleoclimatic implications}

In general, the transitions in the dinocyst and acritarch records, which led us to define stratigraphic zones and bioevents at IODP Site U1307, seem to reflect regional cooling phases. These could be related to the EGC strengthening and the development of the Greenland ice sheet during the PlioPleistocene transition.
Among common taxa recorded at IODP Site U1307, Operculodinium centrocarpum sensu Wall and Dale 1966 is a cosmopolitan modern species particularly abundant in the path of the North Atlantic Current (NAC) (Rochon et al., 1999). In the Plio-Pleistocene sediments of the North Atlantic and the Nordic Seas, this species was interpreted as a marker of the North Atlantic Current (De Schepper et al., 2009, 2013; Hennissen et al., 2014, 2017). The dominance of this species in zone LS1 and the lower half of zone LS2 (Fig. 4) suggests Atlantic water flows into the Labrador Sea possibly through the Irminger Current until about $2.65 \mathrm{Ma}$. At the base of zone LS1, the common occurrence of both Operculodinium? eirikianum var. eirikianum and Operculodinium? eirikianum var. crebrum suggests warm conditions. Operculodinium? eirikianum was reported as a cool-intolerant species by Hennissen et al. (2017). In the Iceland Sea the disappearance of this species in the Early Pliocene was associated with the establishment of the proto-EGC, whereas its continued presence in the Late Pliocene $(<3 \mathrm{Ma})$ Norwegian Sea reflects the continued influence of Atlantic water there (De Schepper et al., 2015). Operculodinium? eirikianum var. crebrum has also been linked to warm, stable conditions following MIS M2 (De Schepper et al., 2013). Hence, at IODP Site U1307; the occurrence of both subspecies of Operculodinium? eirikianum at the base of LS1 (Fig. 4, Table 2) suggests relatively warm Atlantic water influenced sea surface conditions before 3.1 Ma.

At about $2.75 \mathrm{Ma}$, several dinocyst and acritarch taxa have their HO, HPO or HCOs at IODP Site U1307 (Fig. 4, Table 2). Among the taxa, Impagidinium solidum, Ataxiodinium confusum and Invertocysta lacrymosa are Pliocene markers. Their disappearance suggests a regional cooling contemporaneous with the onset of persistent ice-rafted deposition at $\sim 2.72 \mathrm{Ma}$ in response to major expansion of the Greenland ice sheet (Blake-Mizen et al., 2019). Subsequently, between 2.65 and $2.57 \mathrm{Ma}$, we record the acme of Pyxidinopsis braboi at Site U1307 as well as at the eastern North Atlantic DSDP Hole 610A (Hennissen et al., 2014). Pyxidinopsis braboi is interpreted as a cold, polar, opportunistic taxa, and its acme suggests the proximity of the Arctic front (Warny et al., 2009; Hennissen et al., 2014, 2017). After 2.57 Ma, zone LS3 is characterized by the occurrence of typical Late Neogene cool-water species such as Habibacysta tectata, Filisphaera microornata and Filisphaera filifera. These disappeared from the North Atlantic, the Nordic Seas, the Arctic and the North Pacific oceans during the Early Pleistocene after 2.0 Ma (Matthiessen et al., 2018). Filisphaera filifera, Filisphaera microornata and Habibacysta tectata are considered cool-tolerant (De Schepper et al., 2011; Hennissen et al., 2017; Schreck et al., 2017). In the Arctic Ocean, their acme has been associated with the inflow of North Atlantic waters (Matthiessen et al., 2018). However, at North Atlantic DSDP Site 610, a high abundance of Filisphaera filifera characterized the cold MIS M2 (3.26-3.31 Ma; De Schepper et al., 2009), whereas Habibacysta tectata dominated the Early 


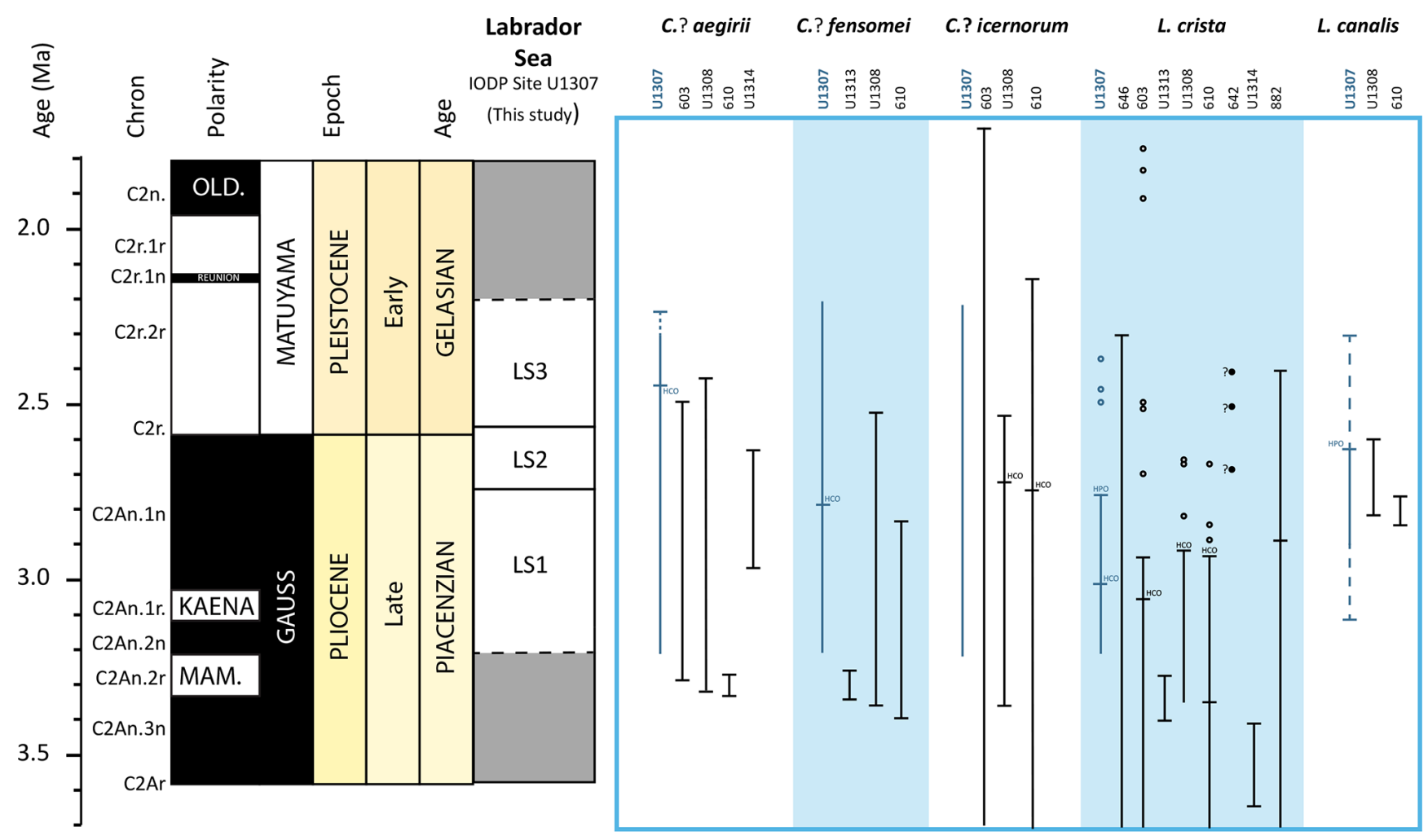

Figure 5. Adapted from De Schepper and Head (2014). Selected acritarch stratigraphic ranges from different sites across the North Atlantic (DSDP Sites 603 and 610; ODP Sites 646, 642 and 907; IODP Sites U1308, U1313 and U1307) and North Pacific (IODP Site U1314, ODP Site 882). Old: Olduvai Subchron; M: Mammoth Subchron; HCO: highest common occurrence; HPO: highest persistent occurrence.

Pleistocene (2.57-2.20 Ma) assemblages and was associated with a reduced influence of Atlantic waters and a southward shift of the NAC (De Schepper et al., 2009; Hennissen et al., 2014). At IODP Site U1307, the increased occurrence of Habibacysta tectata is concomitant with minima of Operculodinium centrocarpum percentages after $2.65 \mathrm{Ma}$, which could be attributed to further surface water cooling.

\subsection{The use of acritarchs in marine palynostratigraphy across the Plio-Pleistocene transition}

Compared to dinocysts, acritarchs are extremely abundant and have a continuous range of occurrence in the Labrador Sea throughout the entire study interval (Figs. 3 and 5). Common taxa from IODP Site U1307 also occurred at other sites from the North Atlantic (De Schepper and Head, 2014), making potential correlation possible between the North Atlantic and the Labrador Sea during the Late Pliocene.

De Vernal and Mudie (1989) defined biostratigraphic Interval II in ODP Hole 646B based on the common to abundant occurrence of Lavradosphaera crista (as Incertae sedis I) until $\sim 2.3 \mathrm{Ma}$, which broadly corresponds to the last appearance of this species at IODP Site U1307, where it is dated at $2.38 \mathrm{Ma}$. The three single occurrences above the HPO at $2.75 \mathrm{Ma}$ may represent reworking (Fig. 5).
Lavradosphaera crista is extremely abundant in middle Late Pliocene of the North Atlantic with an HPO between 3.05 and $2.91 \mathrm{Ma}$ at DSDP Sites 603 and 610 and IODP Site U1308 (De Schepper and Head, 2014). The record of Lavradosphaera crista in the Labrador Sea is also restricted to the Late Pliocene with very abundant specimens between 3.05 and 3.00 Ma. De Schepper and Head (2014) found specimens in the Bering Sea (IODP Site U1314) making the species a potential marker for correlation between the North Pacific and the North Atlantic. However, its stratigraphic distribution in the Bering Sea appears to be restricted to 3.66 to $3.40 \mathrm{Ma}$. Zorzi (2019) extended its geographic distribution to the western North Pacific (ODP Site 882), where specimens are common between $\sim 3.8$ and $\sim 2.9$ Ma. Hence, Lavradosphaera crista could be a good indicator of the middle and late Late Pliocene, not only in the midlatitudes and high latitudes of the North Atlantic but also in the North Pacific.

Cymatiosphaera? fensomei encompasses the entire study interval, from 3.21 to $2.33 \mathrm{Ma}$, thus making it impossible to assess its specific range at IODP Site U1307. Across the North Atlantic, this species has a total range spanning from 3.38 to $2.57 \mathrm{Ma}$ (De Schepper and Head, 2014), making it a good marker for the latest Pliocene. Cymatiosphaera? fensomei in the Labrador Sea is more abundant from 3.08 to $2.76 \mathrm{Ma}$ and the $\mathrm{HCO}$ at $2.76 \mathrm{Ma}$ is distinctive and useful, 
thus adding another Late Pliocene bioevent around 2.75 Ma in the Labrador Sea (Fig. 5). Similarly, Lavradosphaera canalis is found mainly between 2.8 and $2.58 \mathrm{Ma}$ in the Labrador Sea with maximum abundance recorded between 2.8 and $2.75 \mathrm{Ma}$. Other sporadic and single occurrences after the Plio-Pleistocene transition might be related to reworking (Fig. 5) as this species has a very narrow stratigraphic range from 2.8 to $2.6 \mathrm{Ma}$ at IODP Site U1308 and DSDP Site 610A (De Schepper and Head, 2014), suggesting that this taxon is a good marker at midlatitudes and high latitudes of the North Atlantic (Fig. 5).

On the contrary, Cymatiosphaera? icenorum does not seem to have any stratigraphic significance. This species is present throughout our study interval and its total stratigraphic range spans from 5.7 to $1.71 \mathrm{Ma}$ (this study and DSDP 603C, Martin J. Head, unpublished data, in De Schepper et al., 2017). It has its HCO at 2.72 at IODP Site U1308 (De Schepper et al., 2014) and at 2.74 Ma in DSDP Hole 610A (De Schepper and Head, 2009) (Fig. 5).

\section{Conclusion}

We have established a new marine Late Pliocene to Early Pleistocene palynostratigraphic scheme based on the analyses of 178 samples, spanning from 3.2 to $2.2 \mathrm{Ma}$ at the Labrador Sea Site U1307. The succession of three distinct biozones (LS1, LS2 and L3) is based on the HO of Barssidinium graminosum (LS1/LS2) at $2.75 \mathrm{Ma}$ and the end of the acme of Pyxidinopsis braboi (LS2/LS3) at 2.57 Ma. Most sites with comparable biostratigraphical schemes are from the North Atlantic and have been influenced by warm waters from the North Atlantic Current. In contrast, IODP Site U1307 is situated in the path of the East Greenland Current, marked by cold and low-salinity waters of Arctic origin. As a result, a strong regionalism marks the Labrador Sea dinoflagellate cyst and acritarch assemblage, which is reflected in asynchronous bioevents between the North Atlantic, Nordic Seas and Labrador Sea. Nevertheless, despite diachronous stratigraphic ranges for several taxa, our Labrador Sea zone boundaries were constructed with bioevents that are in large part contemporaneous with those of the eastern North Atlantic DSDP Hole 610A (RT5, RT6 and RT7; De Schepper and Head, 2009).

Data availability. All raw data are in Data S2 in the Supplement.

Sample availability. Palynological slides are stored at Geotop, University of Québec in Montréal, Canada, and at the Norwegian Research Centre (NORCE), Bergen, Norway.
Supplement. Data S1 include a list of dinocyst and acritarch taxa, with full authorial citations, from the Late Pliocene to Early Pleistocene of IODP Site U1307. Data S2 include palynomorph counts, including pollen, spores, dinocysts and acritarchs, from 3.2 to $2.2 \mathrm{Ma}$ in sediment samples from IODP Site U1307. Plate $\mathrm{S} 1$ includes photographs of the most biostratigraphically important dinocyst taxa recovered in sediments from IODP Site U1307. Plate S2 includes photographs of the most abundant acritarch taxa and one dinocyst recovered in sediments from IODP Site U1307. The supplement related to this article is available online at: https://doi.org/10.5194/jm-39-41-2020-supplement.

Author contributions. AMRA processed 126 samples, analyzed 175 samples, interpreted results, and wrote and edited the paper.

SDS provided supervision and funding, processed 52 samples, analyzed 37 samples, and participated in interpretation, writing and editing of the paper.

AdV provided supervision and funding, participated in interpretation, writing and editing of the paper.

Competing interests. The authors declare that they have no conflict of interest.

Acknowledgements. This is an ArcTrain contribution. The authors thank the scientific party, technical staff and crew of the Integrated Ocean Drilling Program 303 for their efforts in providing data and samples used in this study. We like to thank Malcolm Jones at Palynological Laboratory Services Ltd. (Holyhead, UK) for aid with preparing palynological slides. We are grateful to Martin J. Head for allowing us to use unpublished data of DSDP 603C. We also thank Peter Bijl, an anonymous reviewer and the editor of this journal for constructive comments, which helped to improve the paper.

Financial support. This research has been supported by the Natural Sciences and Engineering Research Council of Canada (NSERC) and the Fonds de Recherche du Québec Nature et Technologies (FRQNT) (Grants to Anne de Vernal). Stijn De Schepper was funded by Research Council of Norway (project no. 229819).

Review statement. This paper was edited by Emanuela Mattioli and reviewed by Peter Bijl and one anonymous referee.

\section{References}

Andrews, J. T. and Tedesco, K.: Detrital carbonate-rich sediments, northwestern Labrador Sea: Implications for ice-sheet dynamics and iceberg rafting (Heinrich) events in the North Atlantic, Geology, 20, 1087-1090, https://doi.org/10.1130/00917613(1992)020<1087:DCRSNL>2.3.CO;2, 1992.

Baldauf, J. G.: Diatom biostratigraphy of the middle- and highlatitude North Atlantic Ocean, Deep Sea Drilling Project Leg 94, Initial Reports, DSDP, 94, 729-762, 1987. 
Baldauf, J. G., Clement, B. G., Aksu, A. E., de Vernal, A., Firth, J. V., Hall, F., Head, M. J., Jarrad, R. D., Kaminski, M. A., Lazarus, D., Monjanel, A. L., Berggren, W. A., Gradstein, F. E., Knüttel, S., Mudie, P. J., and Russel, M. D.: Magnetostratigraphic and biostratigraphic synthesis of ocean drilling program leg 105: Labrador Sea and Baffin Bay, in: Proceedings of the Ocean Drilling Program, Scientific Results, Vol. 105, edited by by: Srivastava, S. P., Arthur, M. A., Clement, B., Aksu, A., Baldauf, J., Bohrmann, G., Bush, W., Cederberg, T., Cremer, M., Dadey, K., de Vernal, A., Firth, J., Hall, F., Head, M. J., Hiscott, R., Jarrad, R., Kaminski, M. A., Lazarus, D., Monjanel, A.-L., Bjorslev, O., Stein, R., Thiebault, F., Zachos, J., and Zimmerman, H., College Station, TX, Ocean Drilling Program, 935-956, https://doi.org/10.2973/odp.proc.sr.105.165.1989, 1989.

Berggren, W. A., Kent, D. V., and Van Couvering, J. A.: Neogene geochronology and chronostratigraphy, in: Geochronology and the Geologic Time Scale, edited by: Snelling, N. J., Geol. Soc. Mem. (London), 10, 211-250, 1985.

Berggren, W. A., Kent, D. V., Swisher III, C. C., and Aubry, M. P.: A revised Cenozoic geochronology and chronostratigraphy, Geochronology Times Scales and global Stratigraphic Correlation, SEPM Spec. P., 54, 129-212, 1995.

Blake-Mizen, K., Hatfield, R., Stoner, J., Carlson, A., Xuan, C., Walczak, M., Lawrence, K. T., Channell, J. E. T., and Bailey, I.: Southern Greenland glaciation and Western Boundary Undercurrent evolution recorded on Eirik Drift during the late Pliocene intensification of Northern Hemisphere glaciation, Quaternary Sci. Rev., 209, 40-51, https://doi.org/10.1016/j.quascirev.2019.01.015, 2019.

Channell, J. E. T., Kanamatsu, T., Sato, T., Stein, R., Alvarez Zarikian, C. A., Malone, M. J., and the Expedition 303/306 Scientists: Proc. IODP, 303/306: College Station TX (Integrated Ocean Drilling Program Management International, Inc.), https://doi.org/10.2204/iodp.proc.303306.107.2006, 2006.

Channell, J. E. T., Sato, T., Kanamatsu, T., Stein, R., and Alvarez Zarikian, C.: Expedition 303/306 synthesis: North Atlantic climate, in: Proc. IODP, 303/306, edited by: Channell, J. E. T., Kanamatsu, T., Sato, T., Stein, R., Alvarez Zarikian, C. A., Malone, M. J., and the Expedition 303/306 Scientists, College Station, TX, Integrated Ocean Drilling Program Management International, Inc., https://doi.org/10.2204/iodp.proc.303306.214.2010, 2010.

Channell, J. E. T., Hodell, D. A., and Curtis, J. H.: Relative paleointensity (RPI) and oxygen isotope stratigraphy at IODP Site U1308: North Atlantic RPI stack for 1.2-2.2 Ma (NARPI-2200) and age of the Olduvai Subchron, Quaternary Sci. Rev., 131, 119, https://doi.org/10.1016/j.quascirev.2015.10.011, 2016.

Clement, B. M., Hall, F. J., and Jarrad, R. D.: The magnetostratigraphy of Ocean Drilliing Program Leg 105 sediments, in: Proceedings of the Ocean Drilling Program, Scientific Results, Vol. 105, edited by: Srivastava, S. P., Arthur, M. A., Clement, B., Aksu, A., Baldauf, J., Bohrmann, G., Bush, W., Cederberg, T., Cremer, M., Dadey, K., de Vernal, A., Firth, J., Hall, F., Head, M.J., Hiscott, R., Jarrad, R., Kaminski, M. A., Lazarus, D., Monjanel, A.-L., Bjorslev, O., Stein, R., Thiebault, F., Zachos, J., and Zimmerman, H., College Station, TX, Ocean Drilling Program, 583-596, https://doi.org/10.2973/odp.proc.sr.105.147.1989, 1989.

De Schepper, S.: Plio-Pleistocene dinoflagellate cyst biostratigraphy and palaeoecology of the eastern North Atlantic and south- ern North Sea Basin, PhD Thesis, Wolfson College, University of Cambridge, 2006.

De Schepper, S. and Head, M. J.: New dinoflagellate cyst and acritarch taxa from the Pliocene and Pleistocene of the eastern North Atlantic (DSDP Site 610), J. Syst. Palaeontol., 6, 101-117, https://doi.org/10.1017/S1477201907002167, 2008a.

De Schepper, S. and Head, M. J.: Age calibration of dinoflagellate cyst and acritarch events in the Pliocene-Pleistocene of the eastern North Atlantic (DSDP Hole 610A), Stratigraphy, 5, 137-161, 2008b.

De Schepper, S. and Head, M. J.: Pliocene and Pleistocene dinoflagellate cyst and acritarch zonation of DSDP Hole 610A, eastern North Atlantic, Palynology, 33, 179-218, https://doi.org/10.1080/01916122.2009.9989673, 2009.

De Schepper, S. and Head, M. J.: New late Cenozoic acritarchs: evolution, palaeoecology and correlation potential in high latitude oceans, J. Syst. Palaeontol., 12, 493-519, https://doi.org/10.1080/14772019.2013.783883, 2014

De Schepper, S., Head, M. J., and Louwye, S.: New dinoflagellate cyst and incertae sedis taxa from the Pliocene of northern Belgium, southern North Sea Basin, J Paleontol., 78, 625-644, https://doi.org/10.1666/00223360(2004)078<0625:NDCAIS>2.0.CO;2, 2004.

De Schepper, S., Head, M. J., and Groeneveld, J.: North Atlantic Current variability through marine isotope stage M2 (circa 3.3 Ma) during the mid-Pliocene, Paleoceanogr. Paleocl., 24, PA4206, https://doi.org/10.1029/2008PA001725, 2009.

De Schepper, S., Fischer, E. I., Groeneveld, J., Head, M. J., and Matthiessen, J.: Deciphering the palaeoecology of Late Pliocene and Early Pleistocene dinoflagellate cysts, Palaeogeogr. Palaeocl., 309, 17-32, https://doi.org/10.1016/j.palaeo.2011.04.020, 2011.

De Schepper, S., Groeneveld, J., Naafs, B. D. A., Van Renterghem, C., Hennissen, J., Head, M. J., Louwye, S., and Fabian, K.: Northern hemisphere glaciation during the globally warm early late Pliocene, PloS one, 8, 12, https://doi.org/10.1371/journal.pone.0081508, 2013.

De Schepper, S., Schreck, M., Beck, K. M., Matthiessen, J., Fahl, K., and Mangerud, G.: Early Pliocene onset of modern Nordic Seas circulation related to ocean gateway changes, Nat. Commun., 6, 8659, https://doi.org/10.1038/ncomms9659, 2015.

De Schepper, S., Beck, K. M., and Mangerud, G.: Late Neogene dinoflagellate cyst and acritarch biostratigraphy for Ocean Drilling Program Hole 642B, Norwegian Sea, Rev. Palaeobot. Palyno., 236, 12-32, https://doi.org/10.1016/j.revpalbo.2016.08.005, 2017.

de Vernal, A. and Mudie, P. J.: Pliocene and Pleistocene palynostratigraphy at ODP Sites 646 and 647, eastern and southern Labrador Sea, in: Proceedings of the Ocean Drilling Program, Scientific Results, Vol. 105, 401-422, Ocean Drilling Program Texas A \& M University, College Station, Texas, https://doi.org/10.2973/odp.proc.sr.105.134.1989, 1989.

de Vernal, A. and Marret, F.: Organic-walled dinoflagellate cysts: tracers of sea-surface conditions, in: Developments in marine geology, edited by: Hillaire-Marcel, C. and de Vernal, A., Elsevier, 1, 371-408, https://doi.org/10.1016/S1572-5480(07)010147, 2007.

de Vernal, A., Larouche, A., and Richard, P. J. H.: Evaluation of palynomorph concentrations: do the aliquot and the marker-grain 
methods yield comparable results?, Pollen et Spores, 29, 291304, 1987.

de Vernal, A., Henry, M., and Bilodeau, G.: Techniques de préparation et d'analyse en micropaléontologie, Les cahiers du GEOTOP, 3, 20-31, 1999.

de Vernal, A., Radi, T., Zaragosi, S., Van Nieuwenhove, N., Rochon, A., Allan, E., Eynaud, F., Head, M., Limoges, A., Londeix, L., Marret, F., Matthiessen, J., Penaud, A., Pospelova, V., Price, A., and Richerol, T.: Distribution of common modern dinocyst taxa in surface sediment of the Northern Hemisphere in relation to environmental parameters: the updated $n=1968$ database, Mar. Micropaleontol., https://doi.org/10.1016/j.marmicro.2019.101796, online first, 2019.

Dybkjær, K. and Piasecki, S.: Neogene dinocyst zonation for the eastern North Sea Basin, Denmark, Rev. Palaeobot. Palyno., 161, 1-29, https://doi.org/10.1016/j.revpalbo.2010.02.005, 2010.

Expedition 303 Scientists: Site U1307, in: Proc. IODP, 303/306, edited by: Channell, J. E. T., Kanamatsu, T., Sato, T., Stein, R., Alvarez Zarikian, C. A., Malone, M. J., and the Expedition 303/306 Scientists, College Station, TX, Integrated Ocean Drilling Program Management International, Inc., https://doi.org/10.2204/iodp.proc.303306.107.2006, 2006.

Harland, R.: Dinoflagellate biostratigraphy of Neogene and Quaternary sediments at holes 400/400A in the Bay of Biscay (Deep Sea Drilling Project Leg 48), Initial Rep. Deep Sea, 48, 531-545, 1979.

Harrison, J. C., Mayr, U., McNeil, D. H., Sweet, A. R., McIntyre, D. J., Eberle, J. J., Harington, C. R., Chalmers, J. A., Dam, G., and Nohr-Hansen, H.: Correlation of Cenozoic sequences of the Canadian Arctic region and Greenland; implications for the tectonic history of northern North America, B. Can. Petrol. Geol., 47, 223-254, 1999.

Head, M. J.: Dinoflagellates, sporomorphs, and other palynomorphs from the Upper Pliocene St. Erth Beds of Cornwall, southwestern England, Memoir (The Paleontological Society), 31, 1-62, https://doi.org/10.1017/S0022336000061126, 1993.

Head, M. J.: Late Cenozoic dinoflagellates from the Royal Society borehole at Ludham, Norfolk, eastern England, J. Paleontol., 70, 543-570, 1996.

Head, M. J.: Thermophilic dinoflagellate assemblages from the mid Pliocene of eastern England, J. Paleontol., 71, 165-193, https://doi.org/10.1017/S0022336000039123, 1997.

Head, M. J. and Norris, G.: New species of dinoflagellate cysts and other palynomorphs from the latest Miocene and Pliocene of DSDP Hole 603C, western North Atlantic, J. Paleontol., 77, 1-15, https://doi.org/10.1666/00223360(2003)077<0001:NSODCA>2.0.CO;2, 2003.

Head, M. J., Norris, G., and Mudie, P. J.: Palynology and dinocyst stratigraphy of the upper Miocene and lowermost Pliocene, ODP Leg 105, Site 646, Labrador Sea, in: Proceedings of the Ocean Drilling Program, Scientific Results, Vol. 105, 423-451, Ocean Drilling Program Texas A \& M University, College Station, Texas, Palynology and dinocyst stratigraphy of the upper Miocene and lowermost Pliocene, ODP, https://doi.org/10.2973/odp.proc.sr.105.135.1989, 1989.

Head, M. J., Riding, J. B., Eidvin, T., and Chadwick, R. A.: Palynological and foraminiferal biostratigraphy of (Upper Pliocene) Nordland Group mudstones at Sleip- ner, northern North Sea, Mar. Petrol. Geol., 21, 277-297, https://doi.org/10.1016/j.marpetgeo.2003.12.002, 2004.

Hennissen, J. A., Head, M. J., De Schepper, S., and Groeneveld, J.: Palynological evidence for a southward shift of the North Atlantic Current at $\sim 2.6 \mathrm{Ma}$ during the intensification of late Cenozoic Northern Hemisphere glaciation, Paleoceanogr. Paleocl., 29, 564-580, https://doi.org/10.1002/2013PA002543, 2014.

Hennissen, J. A., Head, M. J., De Schepper, S., and Groeneveld, J.: Increased seasonality during the intensification of Northern Hemisphere glaciation at the Pliocene-Pleistocene boundary $\sim 2.6 \mathrm{Ma}$, Quaternary Sci. Rev., 129, 321-332, https://doi.org/10.1016/j.quascirev.2015.10.010, 2015.

Hennissen, J. A., Head, M. J., De Schepper, S., and Groeneveld, J.: Dinoflagellate cyst paleoecology during the Pliocene-Pleistocene climatic transition in the North Atlantic, Palaeogeogr. Palaeocl., 470, 81-108, https://doi.org/10.1016/j.palaeo.2016.12.023, 2017.

Hilgen, F. J., Lourens, L. J., and Van Dam, J. A.: Chapter 29 - The Neogene Period, in: The Geologic Time Scale, edited by: Gradstein, F. M., Ogg, J. G., Schmitz, M. D., and Ogg, G. M., Elsevier, Boston, 923-978, 2012.

Knies, J., Matthiessen, J., Vogt, C., Laberg, J. S., Hjelstuen, B. O., Smelror, M., Larsen, E., Andreassen, K., Eidvin, T., and Vorren, T. O.: The Plio-Pleistocene glaciation of the Barents Sea-Svalbard region: a new model based on revised chronostratigraphy, Quaternary Sci. Rev., 28, 812-829, https://doi.org/10.1016/j.quascirev.2008.12.002, 2009.

Knüttel, S., Russell Jr., M. D., and Firth, J. V.: Neogene calcareous nannofossils from ODP Leg 105: implications for Pleistocene paleoceanographic trends, in: Proceedings of the Ocean Drilling Program, Scientific Results, Vol. 105, edited by: Srivastava, S. P., Arthur, M. A., Clement, B., Aksu, A., Baldauf, J., Bohrmann, G., Bush, W., Cederberg, T., Cremer, M., Dadey, K., de Vernal, A., Firth, J., Hall, F., Head, M. J., Hiscott, R., Jarrad, R., Kaminski, M. A., Lazarus, D., Monjanel, A.-L., Bjorslev, O., Stein, R., Thiebault, F., Zachos, J., and Zimmerman, H., College Station, TX, Ocean Drilling Program, 245-262, https://doi.org/10.2973/odp.proc.sr.105.130.1989, 1989.

Limoges, A., Londeix, L., and de Vernal, A.: Organicwalled dinoflagellate cyst distribution in the Gulf of Mexico, Mar. Micropaleontol., 102, 51-68, https://doi.org/10.1016/j.marmicro.2013.06.002, 2013.

Limoges, A., de Vernal, A., and Van Nieuwenhove, N.: Long-term hydrological changes in the northeastern Gulf of Mexico (ODP625B) during the Holocene and late Pleistocene inferred from organic-walled dinoflagellate cysts, Palaeogeogr. Palaeocl., 414, 178-191, 2014.

Lisiecki, L. E. and Raymo, M. E.: A Pliocene-Pleistocene stack of 57 globally distributed benthic $\delta^{18} \mathrm{O}$ records, Paleoceanography, 20, PA1003, https://doi.org/10.1029/2004PA001071, 2005.

Louwye, S., Head, M. J., and de Schepper, S.: Dinoflagellate cyst stratigraphy and palaeoecology of the Pliocene in northern Belgium, southern North Sea Basin, Geol. Mag., 141, 353-378, https://doi.org/10.1017/S0016756804009136, 2004.

Martini, E.: Standard Tertiary and Quaternary calcareous nannoplankton zonation, in: Proc. II Planktonic Conference, Roma 1970, Roma, Tecnoscienza, 2, 739-785, 1971.

Matthews, J.: The assessment of a method for the determ ination of absolute pollen frequencies, New Phytol., 68, 161-166, 1969. 
Matthiessen, J., Knies, J., Vogt, C., and Stein, R.: Pliocene palaeoceanography of the Arctic Ocean and subarctic seas, Philos. T. R. Soc. A, 367, 21-48, https://doi.org/10.1098/rsta.2008.0203, 2009.

Matthiessen, J., Schreck, M., De Schepper, S., Zorzi, C., and de Vernal, A.: Quaternary dinoflagellate cysts in the Arctic Ocean: Potential and limitations for stratigraphy and paleoenvironmental reconstructions, Quaternary Sci. Rev., 192, 1-26, https://doi.org/10.1016/j.quascirev.2017.12.020, 2018.

Mertens, K. N., Verhoeven, K., Verleye, T., Louwye, S., Amorim, A., Ribeiro, S., Deaf, A. S., Harding, I. C., De Schepper, S., Gonzalez, C., Kodrans-Nsiah, M., de Vernal, A., Henry, M., Radi, T., Dybkjær, K., Poulsen, N. E., Feist-Burkhardt, S., Chitolie, J., Heilmann-Clausen, C., Londeix, L., Turon, J.L., Marret, F., Matthiessen, J., McCarthy, F. M. G., Prasad, V., Pospelova, V., Kyffin Highes, J. E., Riding, J. B., Rochon, A., Sangiorgo, F., Welters, N., Sinclair, N., Thun, C., Soliman, A., Van Nieuwenhove, N., Vink, A., and Young, M.: Determining the absolute abundance of dinoflagellate cysts in recent marine sediments: the Lycopodium marker-grain method put to the test, Rev. Palaeobot. Palyno., 157, 238-252, https://doi.org/10.1016/j.revpalbo.2009.05.004, 2009.

Mudie, P. J.: Palynology and dinoflagellate biostratigraphy of Deep-Sea Drilling Project Leg 94, Sites 607 and 611, North-Atlantic Ocean, Initial Rep. Deep Sea, 94, 785, https://doi.org/10.2973/dsdp.proc.94.118.1987, 1987.

Mudie, P. J.: Palynology and dinocyst biostratigraphy of the late Miocene to Pleistocene, Norwegian Sea: ODP Leg 104, Sites 642 to 644, in: Proceedings of the Ocean Drilling Program, Scientific Results, 104, 587-610, https://doi.org/10.2973/odp.proc.sr.104.174.1989, 1989.

Munsterman, D. and Kerstholt, S.: Sodium polytungstate, a new non-toxic alternative to bromoform in heavy liquid separation, Rev. Palaeobot. Palyno., 91, 417-422, https://doi.org/10.1016/0034-6667(95)00093-3, 1996.

Murphy, M. A. and Salvador, A.: International Stratigraphic Guidean abridged version, Episodes, 22, 255-271, 1999.

Nooteboom, P. D., Bijn, P. K., van Sebille, I., von der Heydt, A. S., and Dijkstra, H. A.: Transport bias by ocean currents in sedimentary microplankton assemblages: implications for paleoceanographic reconstructions, Paleoceanogr. Paleocl., 34, 1178-1194, https://doi.org/10.1029/2019PA003606, 2019.

Price, A. M., Baustian, M. M., Turner, R. E., Rabalais, N. N., and Chmura, G. L.: Melitasphaeridium choanophorum - a living fossil dinoflagellate cyst in the Gulf of Mexico, Palynology, 41, 351-358, 2017.

Rochon, A., Vernal, A. D., Turon, J. L., Matthießen, J., and Head, M. J.: Distribution of recent dinoflagellate cysts in surface sediments from the North Atlantic Ocean and adjacent seas in relation to sea-surface parameters, American Association of Stratigraphic Palynologists Contribution Series, 35, 1-146, 1999.

Sarnthein, M., Bartoli, G., Prange, M., Schmittner, A., Schneider, B., Weinelt, M., Andersen, N., and Garbe-Schönberg, D.: Mid-Pliocene shifts in ocean overturning circulation and the onset of Quaternary-style climates, Clim. Past, 5, 269-283, https://doi.org/10.5194/cp-5-269-2009, 2009.

Schreck, M., Matthiessen, J., and Head, M. J.: A magnetostratigraphic calibration of Middle Miocene through Pliocene dinoflagellate cyst and acritarch events in the Iceland Sea (Ocean
Drilling Program Hole 907A), Rev. Palaeobot. Palyno., 187, 6694, https://doi.org/10.1016/j.revpalbo.2012.08.006, 2012.

Schreck, M., Meheust, M., Stein, R., and Matthiessen, J.: Response of marine palynomorphs to Neogene climate cooling in the Iceland Sea (ODP Hole 907A), Mar. Micropaleontol., 101, 49-67, 2013.

Schreck, M., Nam, S. I., Clotten, C., Fahl, K., De Schepper, S., Forwick, M., and Matthiessen, J.: Neogene dinoflagellate cysts and acritarchs from the high northern latitudes and their relation to sea surface temperature, Mar. Micropaleontol., 136, 51-65, https://doi.org/10.1016/j.marmicro.2017.09.003, 2017.

Schlitzer, R.: Ocean Data View, available at: https://odv.awi.de (last access: 19 February 2020), 2018.

Smelror, M.: Pliocene-Pleistocene and redeposited dinoflagellate cysts from the western Svalbard Margin (Site 986): biostratigraphy, paleoenvironments and sediment provenance, in: Proceedings of the Ocean Drilling Program, scientific results, 162, 8397, 1999.

Stockmarr, J.: Tablets with spores used in absolute pollen analysis, Pollen et Spores, 13, 615-621, 1971.

Thiede, J., Jessen, C., Knutz, P., Kuijpers, A., Mikkelsen, N., Nørgaard-Pedersen, N., and Spielhagen, R. F.: Millions of years of Greenland Ice Sheet history recorded in ocean sediments, Polarforschung, 80, 141-159, 2011.

Verhoeven, K. and Louwye, S.: Palaeoenvironmental reconstruction and biostratigraphy with marine palynomorphs of the PlioPleistocene in Tjörnes, Northern Iceland, Palaeogeogr. Palaeocl., 376, 224-243, https://doi.org/10.1016/j.palaeo.2013.03.002, 2013.

Verhoeven, K., Louwye, S., Paez-Reyes, M., Mertens, K. N., and Vercauteren, D.: New acritarchs from the late Cenozoic of the southern North Sea Basin and the North Atlantic realm, Palynology, 38, 38-50, https://doi.org/10.1080/01916122.2013.793626, 2014.

Versteegh, G. J.: The onset of major Northern Hemisphere glaciations and their impact on dinoflagellate cysts and acritarchs from the Singa section, Calabria (southern Italy) and DSDP Holes 607/607A (North Atlantic), Mar. Micropaleontol., 30, 319-343, https://doi.org/10.1016/S0377-8398(96)00052-7, 1997.

Versteegh, G. J. M. and Zevenboom, D.: New genera and species of dinoflagellate cysts from the Mediterranean Neogene, Rev. Palaeobot. Palyno., 85, 213-229, https://doi.org/10.1016/00346667(94)00127-6, 1995.

Wall, D. and Dale, B.: "Living fossils" in western Atlantic plankton, Nature, 211, 1025-1026, 1996.

Warny, S., Askin, R. A., Hannah, M. J., Mohr, B. A. R., Raine, J. I., Harwood, D. M., Florindo, F., and SMS Science Team: Palynomorphs from a sediment core reveal a sudden remarkably warm Antarctica during the middle Miocene, Geology, 37, 955958, https://doi.org/10.1130/G30139A.1, 2009.

Weaver, A. J., Bitz, C. M., Fanning, A. F., and Holland, M. M.: Thermohaline circulation: High-latitude phenomena and the difference between the Pacific and Atlantic, Annu. Rev. Earth Pl. Sc., 27, 231-285, https://doi.org/10.1146/annurev.earth.27.1.231, 1999.

Weaver, P. E. and Clement, B.: Magnetobiostratigraphy of planktonic foraminiferal datums: Deep Sea Drilling Project Leg 94, North Atlantic, in: Initial Reports of the Deep Sea Drilling Project, edited by: Ruddiman, W. F., Kidd, R. B., Baldauf, J. G., 
Clement, B. M., Dolan, J. F., Eggers, M. R., Hill, P. R., Keigwin Jr., L. D., Mitchell, M., Philipps, I., Robinson, F., Salehipour, S. A., Takayama, T., Thomas, E., Unsold, G., and Weaver, P. P. E., U.S. Government Printing Office, Washington, D.C., 94, 815$829,1987$.

Williams, G. L. and Bujak, J. P.: Cenozoic palynostratigraphy of offshore eastern Canada, American Association of Stratigraphic Palynologists, Contribution Series, 5, 14-47, 1977.

Williams, G. L., Fensome, R. A., and MacRae, R. A.: DINOFLAJ3. American Association of Stratigraphic Palynologists, Data Series no. 2, available at: http://dinoflaj.smu.ca/dinoflaj3 (last access: 19 February 2020), 2017.

Yashayaev, I.: Hydrographic changes in the Labrador Sea, 1960-2005, Prog. Oceanogr., 73, 242-276, https://doi.org/10.1016/j.pocean.2007.04.015, 2007.
Yashayaev, I., Bersch, M., and van Aken, H. M.: Spreading of the Labrador Sea Water to the Irminger and Iceland basins, Geophys. Res. Lett., 34, L10602, https://doi.org/10.1029/2006GL028999, 2007.

Zorzi, C.: Plio-Pleistocene marine palynomorph biostratigraphy of the subartic Pacific, $\mathrm{PhD}$ thesis, Université du Québec à Montréal, QC, Canada, 2019.

Zorzi, C., Head, M. J., Matthiessen, J., and de Vernal, A.: Impagidinium detroitense and I.? diaphanum: Two new dinoflagellate cyst species from the Pliocene of the North Pacific Ocean, and their biostratigraphic significance, Rev. Palaeobot. Palynol., 264, 24-37, https://doi.org/10.1016/j.revpalbo.2019.02.005, 2019. 